\title{
EFFECT OF FOLIAR APPLICATION WITH SALICYLIC ACID AND POTASSIUM SILICATE ON SQUASH PLANTS \\ (Cucurbita pepo L.) YIELD AND QUALITY
}

\author{
Abd-Elaziz. S. A ${ }^{1}$, A. A. Alkharpotly ${ }^{2}$, M. M. Yousry ${ }^{1}$ and A. I. A. Abido ${ }^{1}$ \\ ${ }^{1}$ Plant Production Department, Faculty of Agriculture (Saba Bash), Alexandria \\ University, Egypt. \\ ${ }^{2}$ Horticulture Department, Faculty of Agriculture and Natural Resources, Aswan \\ University, Egypt.
}

\begin{abstract}
Two field experiments were carried out during the summer seasons of 2016 and 2017, in a private farm, at Wadi El-Natroon city, Behiera Governorate, Egypt, under open field conditions in sandy soil. The main objective was to investigate the effectiveness of foliar application of both salicylic acid and potassium silicate on summer squash (Cucumis pepo L. cv. Hollar Queen $\mathrm{F}_{1}$ hybrid) as feeding fertilizers and to overcome the heat stress or over heat of summer temperature (from march to June) during squash plantation (vegetative growth, yield and quality). Treatments were consisted of two factors (two independent variables) as foliar application, i.e.; three concentrations of salicylic acid $(1,2,3 \mathrm{mM})$ or / and four concentrations of potassium silicate $(4.25,8.50,17,34 \mathrm{mM})$ in addition to control plants that's treated with distilled water. Both conducted experiments were in a randomized complete blocks design, with three replications. Each replicate included 20 treatments. All determined treatments were distributed randomly within each block. Squash plants were sprayed with the allocated or assigned treatments twice during the growing seasons, the first one at 25 days after planting (the fourth true leaf stage) and after one week later. The recommended cultural practices for commercial squash production were followed. The obtained results indicated, generally, that foliar application treatments of salicylic acid (SA) and potassium silicate $\left(\mathrm{K}_{2} \mathrm{SiO}_{3}\right)$ alone or in combination to squash plants might be considered as an optimal treatment for the production of high yield and good quality of summer squash. Specifically, the treatment combination between $2 \mathrm{mM}$ salicylic acid plus $8.5 \mathrm{mM}$ potassium silicate might be considered as an optimal treatment to produce high yield and good quality of summer squash under the environmental conditions of Behiera Governorate and other similar regions.
\end{abstract}

Keywords: Squash, salicylic acid, potassium silicate, yield and quality.

Fayoum J. Agric. Res. \& Dev., Vol. 33, No.1, January, 2019 
Summer Squash (Cucurbita pepo L.) belongs to the Cucurbitaceae family, which is one of the most popular vegetable crops for human nutrition in Egypt and worldwide (Abd El-All et al., 2013). The summer Squash has various health benefits to human as well as medicinal potentials. The fruits of squash contain various nutritious properties. It is very low in calories (about 19 $\mathrm{Kcal} / 100 \mathrm{~g}$ ) and has large amount of fiber (Tamer et al., 2010). Nevertheless, during summer seasons, where the predominant high temperature stress, especially in sandy soils, high temperatures exert adverse effect on the growth of the whole plant, especially those above-grounded plant tissues as summer squash which affecting the metabolism, growth and development (Boyer, 1982). Relative to summer squash, more or less, research had examined the effects of heat stress taken place during summer times on this vegetable crop's fruit yield and quality. Also, relatively rare, unless otherwise stated elsewhere, literatures are published concerning affecting summer squash by heat stress and how to manipulate this concern. Hence, overcoming this problem in summer squash could reflect, positively, on growth performance during the time-course of growth and consequently improve both vegetative and reproductive growth. This study hypothesized that salicylic acid (SA) and potassium silicate $\left(\mathrm{K}_{2} \mathrm{SiO}_{3}\right)$ could play a vital role in this context (effect of summer squash by heat stress during summer season). Salicylic acid (SA) acts as an endogenous hormonelike plant growth regulator. It has a role in the secondary metabolism, which encourage of root growth, providing such resistance against infection pathogenesis of the plant, inhibits the biosynthesis of ethylene, and improves the quality and quantity of contained proteins (Canakci and Munzuroglu, 2007). It is, also, plays a vital role in plant growth, ion uptake and transport photosynthetic rate, membrane permeability and transpiration (Wang et al., 2006) it could be affected by SA application. Some studies reported that plant foliar spray with salicylic acid caused increase in vegetative growth, yield and quality as (Elwan and EL-Shatoury, 2014 and Abd El-Mageed et al., 2016) on summer squash and as (AL-Rubaye and Atia, 2016 and Omar, 2017) on cucumber plants. Further, plants typically absorb bio-available silicon ( $\mathrm{Si}$ ) as a silicate, generally, known as monosilicic or orthosilicic acid. Silicon ( $\mathrm{Si}$ ) is deposited as silica in the plant cell walls, improving cell wall structural rigidity and strength, plant architecture and leaf erectness. It has been reported that $\mathrm{Si}$ applied by external foliar treatments or hydroponic supplementation has beneficial effects on plant growth and plays an important role in tolerance of plants to environmental stresses (Balakhnina and Borkowska, 2013; Rizwan et al., 2015). However, further reports indicated that it plays a major role for a variety of plant species as Cucurbitaceae. A number of possible mechanisms through which silicate may increase salinity, heat and drought tolerance in plants have been proposed by various scientists as reviewed by Liang et al.

Fayoum J. Agric. Res. \& Dev., Vol. 33, No.1, January, 2019 
EFFECT OF FOLIAR APPLICATION WITH SALICYLIC ACID 3 (2015), including improved plant water status (Romero-Arnada et al., 2006); increased photosynthetic activity and ultra-structure of leaf organelles (Shu and Liu, 2001). Some investigators reported that plant foliar spray with silicon caused increase in vegetative growth, yield and quality of cucumber plants as (Jafari et al., 2015 and Omar, 2017). There is a shortage information regarding the significant benefits of $\mathrm{Si}$ fertilization to summer squash, and it highlights such significance for future prospects of research in this field. Due to limit of knowledge regarding manipulating the heat stress practiced on the of summer squash during cultivation season, the main objective behind this study was to investigate the effectiveness of foliar application of both salicylic acid and potassium silicate on summer squash (Cucumis pepo L. cv. Hollar Queen $F_{1}$ hybrid) as feeding fertilizers during both summer seasons (from march to June) of squash plantation led to increasing on vegetative growth, yield and quality.

\section{MATERIALS AND METHODS}

\section{Experimental sites and arrangement:}

Two field experiments were carried out during the summer seasons of 2016 and 2017, in a private farm, at Wadi El-Natroon city, Behiera Governorate, Egypt, under open field conditions in a sandy soil. Before planting, random soil samples of $30 \mathrm{~cm}$ depth from different places of the planting field were collected and analyzed for some important chemical and physical properties according to Wilde $\boldsymbol{e t}$ al., $\mathbf{1 9 8 5}$ is given in Table (1). The experimental field was polughed and pulverized. Then, the soil was ridged into rows onemeter width and divided to plots. Squash seeds were sown directly in the field on March $18^{\text {th }}$ during both seasons at $0.5 \mathrm{~m}$ apart and $1 \mathrm{~m}$ width of ridge on one side of the rows. After germination, plants were thinned leaving one plant per hill. The experimental plot consisted of one ridge with $10.5 \mathrm{~m}$ long and $1 \mathrm{~m}$ width; making an area of $10.5 \mathrm{~m}^{2}$. A drip irrigation network system was designed for this study. Both conducted experiments were in a randomized complete blocks design, with three replicates. Each replicate included 20 treatments.

\section{Experimental materials:}

Gynoecious squash cultivar' seeds coined as "Hollar Queen $F_{1}$ hybrid" was used for conducting the experimentation step. It was purchased form Hollar Seeds Rocky Ford Co., USA. Imported by World of Agriculture\& Veterinary Co. (WAV Co), El-Giza, Egypt.

Treatments were consisted of two factors as a foliar application, i.e.; three concentrations of salicylic acid $(1,2,3 \mathrm{mM})$ or / and four concentrations of potassium silicate $(4.25,8.50,17,34 \mathrm{mM})$ in addition to control plants that treated with distilled water. All determined treatments were distributed randomly within each block as reported earlier. Squash plants were sprayed with the allocated or assigned treatments twice during the growing seasons, the first one at 25 days after planting (the fourth true leaf stage) and

Fayoum J. Agric. Res. \& Dev., Vol. 33, No.1, January, 2019 
Abd-Elaziz. S. A A $^{1}$, et al.,

Table (1): Physical and chemical properties of the experimental site during both seasons of the experimentation (2016 and 2017).

\begin{tabular}{|c|c|c|}
\hline \multirow{2}{*}{ Soil properties } & \multicolumn{2}{|c|}{ Season } \\
\hline & 2016 & 2017 \\
\hline \multicolumn{3}{|l|}{ Physical analysis: } \\
\hline Clay $(\%)$ & 3 & 3.5 \\
\hline Silt $(\%)$ & 0 & 0 \\
\hline Sand $(\%)$ & 97 & 96.5 \\
\hline Textural class & Sandy & Sandy \\
\hline \multicolumn{3}{|l|}{ Chemical analysis: } \\
\hline \multicolumn{3}{|c|}{ Soluble cations in (1:5) soil: water extract (meq/l) } \\
\hline $\mathrm{Ca}^{++}$ & 1.7 & 1.6 \\
\hline $\mathrm{Mg}^{++}$ & 2.04 & 2.00 \\
\hline $\mathrm{K}^{+}$ & 0.51 & 0.45 \\
\hline $\mathrm{Na}^{+}$ & 1.60 & 1.80 \\
\hline \multicolumn{3}{|c|}{ Soluble anions in (1:5) soil: water extract (meq/l) } \\
\hline $\mathrm{HCO}_{3}^{-}$ & 4.5 & 4.60 \\
\hline $\mathrm{Cl}^{-}$ & 2.4 & 2.35 \\
\hline $\mathrm{SO}_{4}^{--}$ & 0.81 & 0.80 \\
\hline $\mathrm{pH}(1: 1$ soil suspension $)$ & 7.87 & 8.10 \\
\hline $\mathrm{EC}$ at $25^{\circ} \mathrm{C}(\mathrm{ds} / \mathrm{m})$ & 0.44 & 0.45 \\
\hline $\mathrm{CaCO}_{3}$ & 2.1 & 2.20 \\
\hline O.M. & 0.07 & 0.09 \\
\hline Available N (mg/kg soil) & 267.53 & 265.50 \\
\hline Available $\mathrm{P}$ (mg/kg soil) & 30.25 & 33.25 \\
\hline Available K (mg/kg soil) & 200 & 220 \\
\hline
\end{tabular}

-The analyses were carried out at Soil Departement, Faculty of Agricultur (Saba Basha), Alexanderia University, Egypt.

after one week later. The recommended cultural practices for commercial squash production in the area were followed.

3. Harvesting: Harvesting of the fruits was done for early yield after 40 days, then for the rest of harvesting cycles (each 4 days during both seasons). The harvesting fruits were counted and weight using electronic scale.

\section{Experimental data collections}

Four plants form each treatment in each replication were, randomly, selected and tagged for recording growth, early yield and total yield as well as fruits quality parameters.

\subsection{Vegetative growth}

4.1.1. Plant height $(\mathbf{c m})$ It was recorded in centimeters from the base of the plant to the terminal growing point of tagged plants after 40 days from planting date using a meter scale.

4.1.2. Number of leaves per plant, were counted after 40 days from planting date.

4.1.3. Plant fresh weight (g) was determined as the average fresh weight of plant foliage after 45 days of planting.

4.1.4. Plant dry weight (g): Plant foliage was dried in an electrical oven at $70^{\circ} \mathrm{C}$ till the constant weight, then the average dry weight of whole plant foliage was determined in gram.

Fayoum J. Agric. Res. \& Dev., Vol. 33, No.1, January, 2019 
EFFECT OF FOLIAR APPLICATION WITH SALICYLIC ACID 5

4.2. Flowering characteristics: Four plants from each experimental plot were chosen at random, and the following data were recorded:

4.2.1. Number of flowers/plant: The whole numbers of the opened flowers/ plant all over the season were counted.

4.2.2. Fruits setting percentage $(\%)$ : It was calculated by dividing number of fruits/plant by number of flowers/plant multiplied by 100 .

4.3. Fruits yield parameters:

4.3.1. Number of fruits/plant: The average of fruits' number/plant was determined from the total number of fruits harvested over the entire harvest period (36 days).

4.3.2. Fruits yield/plant $(\mathbf{k g})$ : The average of fruit weight/plant was calculated from the fruit harvested over the all picking times.

4.3.3. Fruits yield/feddan (ton): The total fruit weight from the tagged plants was recorded and fruits yield/feddan was determined as:

Fruits yield per feddan =average fruits yield/plant $\mathrm{x}$ number of plants/feddan.

4.3.4. Average fruits weight (g): It was calculated as total fruits yield (g)/ total number of fruits per plant.

4.3.5. Early yield: it was considered as the weight of all harvested fruits during the first 4 pickings of harvesting per plant $(\mathrm{g})$ and per feddan expressed in $(\mathrm{kg})$.

4.3.6. Fruits dry weight $(\mathrm{g})$ : Randomly fruit samples of $100 \mathrm{~g}$ of fresh weight were dried in an electrical oven at $70^{\circ} \mathrm{C}$ till the constant weight then the average of fruit dry weight was calculated in $(\mathrm{g})$.

4.4. Fruit quality: Four fruits were, randomly, taken from each plot of all pickings to study the morphological and chemical characters of the fruits during both seasons of the study.

4.4.1. Morphological characters: Fruit length $(\mathrm{cm})$ and fruit diameter $(\mathrm{cm})$ were measured and fruit shape index was calculated as (fruit length/ fruit diameter).

4.4.2. Chemical composition: The following fruits constituents were determined in fruits samples that collected for chemical characteristics determination as follows:

4.4.2.1.Total soluble solids content (TSS \%): It was estimated in the juice of the fresh fruits using a hand refractometer according to A.O.A.C. (1992).

4.4.2.2.Total titratable acidity (\%): It was determined in the fruit juice, as citric acid percent (mg/100 $\mathrm{cm}^{3}$ juice) as the method described in the A.O.A.C. (1992).

4.4.2.3.Total, reducing and non-reducing sugars: They were determined for each fruits sample according to the method described by Malik and Singh (1980).

4.5. Plant chemical analysis

4.5.1. N, P, K, Si contents of leaves and fruits: The kjeldahel digestion procedure was conducted as described by Okalebo et al. (2002). The total nitrogen in plant samples was determined using the micro kjeldahel method of distillation and titration as described by Pregl (1945). Total $\mathrm{P}$ was determined following color development using the Bray P1 extractant, measured by the Murphy blue coloration (Murphy and Riley, 1962) using a Spectrophotometer (model Perkin Elmer Lamda 45). Total $\mathrm{K}$ was determined by aspirating directly into Jenway flame

Fayoum J. Agric. Res. \& Dev., Vol. 33, No.1, January, 2019 
Abd-Elaziz. S. A ${ }^{1}$, et al.,

photometer (PFP7). Reactive silica was analyzed according to molybdsilicate method described in APHA (1992).

4.5.2. Leaf chlorophyll indication (SPAD) : For determination chlorophyll readings, at harvest,leaf greenness was done using a non- destructive method using a SPAD 502 chlorophyll meter for each plant, 3 recently full- expanded leaves were randomly chosen for SPAD (Soil Plant Analysis Development) measurement at the average of 3 readings was recoded (Yadava, 1985; Marquard and Tipton, 1987).

\section{Statistical Analysis :}

All obtained data of the present study were, statistically, analyzed according to the design used by the MSTAT-C computer software program (Bricker, 1991) and were tested by analysis of variance. The comparisons among the means of different treatments were carried out, using the revised least significant difference test at 0.05 level of probability was used to compare the differences among the means of the various treatment combinations as illustrated by (El-Rawy and Khalf-Allah, 1980; Gomez and Gomez, 1984).

Meteorological data of the cultivation area during time-course of conducting the present study are illustrated in Table (2).

table (2): The maximum, minimum and average air temperatures per week during the two growing seasons of 2016 and 2017.

\begin{tabular}{|c|c|c|c|c|c|c|}
\hline \multirow{2}{*}{ weeks } & \multicolumn{3}{|c|}{ Air temperature [ $\left.{ }^{\circ} \mathbf{C}\right]$} & \multicolumn{3}{c|}{ Air temperature [ $\left.{ }^{\circ} \mathbf{C}\right]$} \\
\cline { 2 - 7 } & Max. & Min. & $\mathbf{x}^{-}$ & Max. & Min. & $\mathbf{x}^{-}$ \\
\cline { 2 - 7 } & \multicolumn{3}{|c|}{$\mathbf{2 0 1 6}$} & & \multicolumn{3}{|c|}{$\mathbf{2 0 1 7}$} \\
\hline 25-31 Mar. & 23.10 & 12.20 & 17.65 & 21.05 & 11.00 & 16.03 \\
\hline 01-07 Apr. & 22.15 & 10.11 & 16.13 & 24.55 & 11.00 & 17.50 \\
\hline 08 -14 Apr. & 26.10 & 10.00 & 18.05 & 22.70 & 11.20 & 16.95 \\
\hline 15- 21Apr. & 26.10 & 13.00 & 19.55 & 22.80 & 12.80 & 17.80 \\
\hline 22- 28 Apr. & 28.90 & 11.50 & 20.20 & 28.10 & 11.40 & 19.75 \\
\hline 29 Apr.-05 May & 29.50 & 13.70 & 21.60 & 28.50 & 12.40 & 20.45 \\
\hline 06-12 May & 25.80 & 13.70 & 19.75 & 24.90 & 12.70 & 18.80 \\
\hline 13- 19 May & 31.30 & 15.70 & 23.50 & 31.50 & 14.90 & 23.20 \\
\hline 20- 26 May & 29.00 & 16.60 & 22.80 & 30.50 & 16.50 & 23.50 \\
\hline 27 May-02 june & 27.59 & 16.15 & 21.87 & 30.00 & 14.40 & 22.20 \\
\hline 03-09 june & 34.00 & 17.90 & 25.95 & 30.40 & 16.10 & 23.25 \\
\hline 10-16 june & 32.00 & 17.70 & 24.85 & 31.00 & 18.40 & 24.70 \\
\hline 17-23 june & 32.20 & 18.70 & 25.45 & 31.50 & 18.00 & 24.75 \\
\hline
\end{tabular}

Meteorological data from Central Lab. for Agricultural Climate, Agricultural Research Center, Ministry of Agriculture and Land Reclamation, Egypt.

\section{RESULTS AND DISCUSSION}

1. Vegetative growth characters: The results in Table (3) illustrated that all SA and potassium silicate treatments when used singly or in combination on squash plants, significantly, increased all vegetative growth characters comparing to non-treated plants during both seasons. Generally, untreated plants showed the lowest significant average values for all vegetative growth characters. Results, also, showed nonsignificant effects among the treatments of

Fayoum J. Agric. Res. \& Dev., Vol. 33, No.1, January, 2019 
EFFECT OF FOLIAR APPLICATION WITH SALICYLIC ACID.......... 7

salicylic acid and potassium silicate and their combinations on plant height during both seasons of the study, and plant dry weight, during the first season only, while during the second season, the recorded results indicated that the highest average values were taken place due to foliar application with salicylic acid at $1 \mathrm{mM}$ for both plant height characters (54.00 and $56.67 \mathrm{~cm}$; respectively) and $3 \mathrm{mM}$ or $8.5 \mathrm{mM}$ potassium silicate concentrations for plant dry weight characters as 141.90 or $135.77(\mathrm{~g})$, during second season each in turn. Regarding number of leaves per plant character, the combination between $2 \mathrm{mM}$ salicylic acid plus $17 \mathrm{mM}$ potassium silicate; gave rise the highest average values during both seasons as 29.33 and 29.00, consecutively. In the case of plant fresh weight character, foliar application with $8.5 \mathrm{mM}$ potassium silicate showed the highest average values as 887 and 877 (g) serially, during both seasons of the study. Generally, in terms of the main effects of both SA and potassium silicate $\left(\mathrm{K}_{2} \mathrm{SiO}_{4}\right)$ and their combinations, the tabulated results indicated, clearly, their modes of action in regulating and modulating the physiological processes on growth and development of summer squash under the study via ion uptake and transport, photosynthetic rate, membrane permeability and transpiration (Bhupinder and Usha, 2003; Wang et al., 2006). The favorable of $\mathrm{Si}$ application resulted in its ability to hamper both biotic pressures caused by pest attacks and plant diseases, as well as biotic pressures, including physical pressures such as water logging, drought, high temperature, freezing, UV, and chemical pressures as nutrient deficiencies, salinity, and metal toxicity (Zhu and Gong, 2014; Rizwan et al., 2015). Also, the role of $\mathrm{Si}$ in protecting the plant cell membranes from oxidative damage when grown under stress as heating. Consequently, Si may be contributing in many physiological or metapolic changes that stimulate plant growth (Zhu $e$ t al., 2004). Regarding SA effects, the presented results in this study are in harmony, more or less, with those of (Elwan and EL-Shatoury, 2014) who reported that compared to control treatment, squash plants sprayed with SA had 2.3 and 1.4 times produced more leaves and 3.2 and 2.5 times higher fresh weight during both seasons of their study, respectively.

Fayoum J. Agric. Res. \& Dev., Vol. 33, No.1, January, 2019 
Table (3): Averages of some vegetative growth-related characters of squash plants as affected by foliar application with salicylic acid, potassium silicate and their combinations during the summer seasons of 2016 and 2017.

\begin{tabular}{|c|c|c|c|c|c|c|c|c|c|}
\hline \multirow{2}{*}{\multicolumn{2}{|c|}{ Treatments }} & \multicolumn{2}{|c|}{$\begin{array}{c}\text { Plant height } \\
(\mathrm{cm})\end{array}$} & \multicolumn{2}{|c|}{ No. of leaves/plant } & \multicolumn{2}{|c|}{$\begin{array}{c}\text { Plant fresh weight } \\
\text { (g) }\end{array}$} & \multicolumn{2}{|c|}{$\begin{array}{c}\text { Plant dry weight } \\
\text { (g) }\end{array}$} \\
\hline & & 2016 & 2017 & 2016 & 2017 & 2016 & 2017 & 2016 & 2017 \\
\hline $1-$ & Control & $43.33 \mathrm{~b}$ & $43.33 \mathrm{e}$ & $22.67 \mathrm{e}$ & $22.33 \mathrm{~d}$ & $470 \mathrm{e}$ & $502 \mathrm{e}$ & $89.76 \mathrm{a}$ & $68.97 \mathrm{e}$ \\
\hline $2-$ & $1 \mathrm{mM}(\mathrm{SA})$ & $54.00 \mathrm{a}$ & $56.67 \mathrm{a}$ & $26.67 \mathrm{a}-\mathrm{d}$ & $26.00 \mathrm{c}$ & $678 \mathrm{bc}$ & 707 a-c & $112.83 \mathrm{a}$ & $117.43 \mathrm{a}-\mathrm{d}$ \\
\hline $3-$ & $2 \mathrm{mM}(\mathrm{SA})$ & $51.67 \mathrm{ab}$ & 50.00 a-e & $28.00 \mathrm{a}-\mathrm{d}$ & $27.67 \mathrm{a}-\mathrm{c}$ & $825 \mathrm{ab}$ & $812 \mathrm{ab}$ & $121.70 \mathrm{a}$ & $121.20 \mathrm{a}-\mathrm{d}$ \\
\hline 4- & $3 \mathrm{mM}(\mathrm{SA})$ & $50.00 \mathrm{ab}$ & $50.00 \mathrm{a}-\mathrm{e}$ & $27.00 \mathrm{a}-\mathrm{d}$ & $27.33 \mathrm{a}-\mathrm{c}$ & $620 \mathrm{c}-\mathrm{e}$ & $667 \mathrm{~b}-\mathrm{e}$ & $111.87 \mathrm{a}$ & $141.90 \mathrm{a}$ \\
\hline $5-$ & $4.25 \mathrm{mM}\left(\mathrm{K}_{2} \mathrm{SiO}_{3}\right)$ & $51.00 \mathrm{ab}$ & 50.00 a-e & $26.00 \mathrm{a}-\mathrm{d}$ & $26.00 \mathrm{c}$ & $690 \mathrm{bc}$ & $713 a-c$ & $101.63 \mathrm{a}$ & $105.03 \mathrm{a}-\mathrm{e}$ \\
\hline $6-$ & $8.5 \mathrm{mM}\left(\mathrm{K}_{2} \mathrm{SiO}_{3}\right)$ & $51.33 \mathrm{ab}$ & 50.00 a-e & $28.33 \mathrm{a}-\mathrm{d}$ & $29.00 \mathrm{a}$ & $887 \mathrm{a}$ & $877 \mathrm{a}$ & $136.23 \mathrm{a}$ & $135.77 \mathrm{a}$ \\
\hline $7-$ & $17 \mathrm{mM}\left(\mathrm{K}_{2} \mathrm{SiO}_{3}\right)$ & $46.67 \mathrm{ab}$ & $45.00 \mathrm{de}$ & $27.33 \mathrm{a}-\mathrm{d}$ & $26.00 \mathrm{c}$ & $488 \mathrm{de}$ & $565 \mathrm{c}-\mathrm{e}$ & $82.42 \mathrm{a}$ & $89.90 \mathrm{~b}-\mathrm{e}$ \\
\hline $8-$ & $34 \mathrm{mM}\left(\mathrm{K}_{2} \mathrm{SiO}_{3}\right)$ & $49.00 \mathrm{ab}$ & 50.00 a-e & $26.67 \mathrm{a}-\mathrm{d}$ & $26.67 \mathrm{bc}$ & $663 \mathrm{bc}$ & $680 \mathrm{~b}-\mathrm{d}$ & $122.37 \mathrm{a}$ & $126.70 \mathrm{a}-\mathrm{d}$ \\
\hline 9- & $1 \mathrm{mM}(\mathrm{SA})+4.25 \mathrm{mM}\left(\mathrm{K}_{2} \mathrm{SiO}_{3}\right)$ & $50.00 \mathrm{ab}$ & $53.33 \mathrm{a}-\mathrm{c}$ & $26.67 \mathrm{a}-\mathrm{d}$ & $27.33 \mathrm{a}-\mathrm{c}$ & $672 \mathrm{bc}$ & $650 \mathrm{~b}-\mathrm{e}$ & $108.70 \mathrm{a}$ & $112.53 \mathrm{a}-\mathrm{d}$ \\
\hline $10-$ & $1 \mathrm{mM}(\mathrm{SA})+8.5 \mathrm{mM}\left(\mathrm{K}_{2} \mathrm{SiO}_{3}\right)$ & $47.00 \mathrm{ab}$ & $46.67 \mathrm{c}-\mathrm{e}$ & $25.33 \mathrm{c}-\mathrm{e}$ & $26.67 \mathrm{bc}$ & $467 \mathrm{e}$ & $533 \mathrm{de}$ & $78.40 \mathrm{a}$ & $88.50 \mathrm{c}-\mathrm{e}$ \\
\hline $11-$ & $1 \mathrm{mM}(\mathrm{SA})+17 \mathrm{mM}\left(\mathrm{K}_{2} \mathrm{SiO}_{3}\right)$ & $51.67 \mathrm{ab}$ & $53.33 \mathrm{a}-\mathrm{c}$ & $27.67 \mathrm{a}-\mathrm{d}$ & $27.33 \mathrm{a}-\mathrm{c}$ & $730 \mathrm{a}-\mathrm{c}$ & $710 \mathrm{a}-\mathrm{c}$ & $128.07 \mathrm{a}$ & $128.63 \mathrm{a}-\mathrm{d}$ \\
\hline $12-$ & $1 \mathrm{mM}(\mathrm{SA})+34 \mathrm{mM}\left(\mathrm{K}_{2} \mathrm{SiO}_{3}\right)$ & $50.00 \mathrm{ab}$ & $49.33 \mathrm{~b}-\mathrm{e}$ & $26.67 \mathrm{a}-\mathrm{d}$ & $26.67 \mathrm{bc}$ & $577 \mathrm{c}-\mathrm{e}$ & $580 \mathrm{c}-\mathrm{e}$ & $82.33 \mathrm{a}$ & $87.57 \mathrm{de}$ \\
\hline 13- & $2 \mathrm{mM}(\mathrm{SA})+4.25 \mathrm{mM}\left(\mathrm{K}_{2} \mathrm{SiO}_{3}\right)$ & $52.33 \mathrm{a}$ & $53.00 \mathrm{a}-\mathrm{c}$ & $28.00 \mathrm{a}-\mathrm{c}$ & $28.67 \mathrm{ab}$ & $487 \mathrm{de}$ & $551 \mathrm{c}-\mathrm{e}$ & $87.63 \mathrm{a}$ & $91.07 \mathrm{~b}-\mathrm{e}$ \\
\hline 14- & $2 \mathrm{mM}(\mathrm{SA})+8.5 \mathrm{mM}\left(\mathrm{K}_{2} \mathrm{SiO}_{3}\right)$ & $53.33 \mathrm{a}$ & $54.33 \mathrm{ab}$ & $27.00 \mathrm{a}-\mathrm{d}$ & $27.00 \mathrm{a}-\mathrm{c}$ & $642 \mathrm{~cd}$ & $657 \mathrm{~b}-\mathrm{e}$ & $121.97 \mathrm{a}$ & $131.70 \mathrm{ab}$ \\
\hline $15-$ & $2 \mathrm{mM}(\mathrm{SA})+17 \mathrm{mM}\left(\mathrm{K}_{2} \mathrm{SiO}_{3}\right)$ & $54.33 \mathrm{a}$ & $52.67 \mathrm{a}-\mathrm{c}$ & $29.33 \mathrm{a}$ & $29.00 \mathrm{a}$ & $693 \mathrm{bc}$ & $717 \mathrm{a}-\mathrm{c}$ & $110.23 \mathrm{a}$ & $130.03 \mathrm{a}-\mathrm{c}$ \\
\hline $16-$ & $2 \mathrm{mM}(\mathrm{SA})+34 \mathrm{mM}\left(\mathrm{K}_{2} \mathrm{SiO}_{3}\right)$ & $46.33 \mathrm{ab}$ & $48.00 \mathrm{a}-\mathrm{d}$ & $26.33 \mathrm{a}-\mathrm{d}$ & $27.00 \mathrm{a}-\mathrm{c}$ & $707 \mathrm{bc}$ & 710 a-c & $113.30 \mathrm{a}$ & $113.50 \mathrm{a}-\mathrm{d}$ \\
\hline $17-$ & $3 \mathrm{mM}(\mathrm{SA})+4.24 \mathrm{mM}\left(\mathrm{K}_{2} \mathrm{SiO}_{3}\right)$ & $50.00 \mathrm{ab}$ & $51.67 \mathrm{a}-\mathrm{c}$ & $24.67 \mathrm{de}$ & $26.67 \mathrm{bc}$ & $592 \mathrm{c}-\mathrm{e}$ & $560 \mathrm{c}-\mathrm{e}$ & $98.97 \mathrm{a}$ & $100.20 \mathrm{a}-\mathrm{e}$ \\
\hline $18-$ & $3 \mathrm{mM}(\mathrm{SA})+8.5 \mathrm{mM}\left(\mathrm{K}_{2} \mathrm{SiO}_{3}\right)$ & $46.33 \mathrm{ab}$ & $45.00 \mathrm{a}-\mathrm{e}$ & $25.33 \mathrm{c}-\mathrm{e}$ & $26.00 \mathrm{c}$ & $572 \mathrm{c}-\mathrm{e}$ & $547 \mathrm{c}-\mathrm{e}$ & $87.80 \mathrm{a}$ & $93.53 \mathrm{~b}-\mathrm{e}$ \\
\hline 19- & $3 \mathrm{mM}(\mathrm{SA})+17 \mathrm{mM}\left(\mathrm{K}_{2} \mathrm{SiO}_{3}\right)$ & $46.00 \mathrm{ab}$ & $50.00 \mathrm{ab}$ & $24.67 \mathrm{de}$ & $26.67 \mathrm{bc}$ & $590 \mathrm{c}-\mathrm{e}$ & $590 \mathrm{c}-\mathrm{e}$ & $97.47 \mathrm{a}$ & $92.33 \mathrm{~b}-\mathrm{e}$ \\
\hline $20-$ & $3 \mathrm{mM}(\mathrm{SA})+34 \mathrm{mM}\left(\mathrm{K}_{2} \mathrm{SiO}_{3}\right)$ & $54.33 \mathrm{a}$ & $53.67 \mathrm{a}-\mathrm{c}$ & $29.00 \mathrm{ab}$ & $28.67 \mathrm{ab}$ & $620 \mathrm{c}-\mathrm{e}$ & $655 \mathrm{~b}-\mathrm{e}$ & $95.93 \mathrm{a}$ & 105.93 a-e \\
\hline
\end{tabular}

- SA, salicylic acid; $\mathrm{K}_{2} \mathrm{SiO}_{3}$, potassium silicate. Values having the same alphabetical letter (s) in common, within each column, do not significantly differ, using the revised L.S.D. test at 0.05 level of probability.

Also, Abd El-Mageed et al. (2016) illustrated that exogenous SA application, significantly, increased all squash growth parameters (i. e. shoot length, number of leaves per plant, leaf area per plant and shoot and root dry weights per plant) during both summer and fall seasons. AL-Rubaye and Atia (2016) exhibited that the tallest squash plant height was found to be due to foliar application 5 $\mathrm{mM}$ concentration of salicylic acid compared to the other applied concentrations. Omar (2017) illustrated that foliar application of SA at 200 ppm caused; significant increase on cucumber stem length, number of branches, leaf area and plant fresh and dry weights compared to control plants (sprayed with tap water). Yildirim et al. (2008) found that foliar applications of SA; resulted in greater cucumber shoot fresh and dry weights, root fresh weight and dry weights, higher plants, stem diameter and leaf number per plant under salt stress condition.

Fayoum J. Agric. Res. \& Dev., Vol. 33, No.1, January, 2019 
EFFECT OF FOLIAR APPLICATION WITH SALICYLIC ACID 9

Regarding ( $\mathrm{Si}$ ) spraying, the present findings were similar, more or less, with those reported by Al-Aghabary et al. (2005) who found that Si foliar application; resulted in increasing dry matter accumulated in all parts of tomato plants under salt stress and the increase in leaf and total plant dry matter content was significant. The increase was to the extent of 19.5, 25.4, 13.4, and $21.2 \%$ with leaf, stem, root, and total plant, serially. Also, Romero-Aranda et al. (2006) demonstrated that the application of $2.5 \mathrm{mM}$ silicon; gave rise to an increase in plant dry weight and leaf area of tomato plants. Further, Li et al. (2015) demonstrated that application of $2 \mathrm{mM} \mathrm{Si}$ in sand culture; was accounted with improved total root length, plant height, leaf area and dry weights of both shoots and roots of tomato plants. Concerning the combinations between both $\mathrm{SA}$ and $\mathrm{Si}$ concentrations, Jafari et al. (2015) reported that under osmotic stress, $\mathrm{Si}, \mathrm{SA}$ and $\mathrm{Si}+\mathrm{SA}$, increased leaf area, shoot fresh and dry matter contents of cucumber plants.

\section{Flowering characters:}

Results presented in Table (4) declared that both tested characters, i.e. numbers of flower/plant and fruit setting percentage of squash plants were affected, significantly, owing to combinations of tested foliar application items under investigation. Foliar spray with 17 or $34 \mathrm{mM}$ potassium silicate during first season, and the combination between $2 \mathrm{mM}$ of $\mathrm{SA}$ and $8.5 \mathrm{mM}$ of potassium silicate during both seasons; brought about the highest significant average values for number of flowers/plant character as 16.67 for the former and 16.67 and 17.00 for the later compared to untreated plants. The lowest significant average values were obtained from untreated plants (10.00-12.67) during both seasons, respectively. These results are in consistent trend with those of Kazemi (2014) on tomato. The same author indicated that salicylic acid $(0.5 \mathrm{mM})$ alone or in combination $(0.5 \mathrm{mM} \mathrm{SA}+0.25 \mathrm{mM} \mathrm{MJ})$; increased number of flower branches per plant. Also, on strawberry plants, Jamali et al. (2011) indicated that $\mathrm{SA}$ at $2 \mathrm{mM}$; increased inflorescence number and flower number per inflorescence. As for fruit setting percentage character during the first season, treatment of $2 \mathrm{mM}$ salicylic acid plus $17 \mathrm{mM}$ potassium silicate; led to the highest average value of the given trait, while the lowest average values were obtained from application with $2 \mathrm{mM}$ or $1 \mathrm{mM} \mathrm{SA}$ with either 4.25 $\mathrm{mM}\left(\mathrm{K}_{2} \mathrm{SiO}_{4}\right)$ or $8.5 \mathrm{mM}\left(\mathrm{K}_{2} \mathrm{SiO}_{4}\right)$. On the other hand, during the second season, nonsignificant effects were noticed among all treatments and untreated plants.

\section{Yield characters:}

Results presented in Tables (5 and 6) expressed that foliar application with SA and potassium silicate and their combinations; affected significantly $(p \leq 0.05)$ all studied characteristics of the tested squash cultivar (i.e. number of fruit, average fruit fresh and dry weights, early fruit yield per plant and per feddan and total fruit yield per plant and per feddan). Whereas, the lowest

Fayoum J. Agric. Res. \& Dev., Vol. 33, No.1, January, 2019 
Abd-Elaziz. S. A ${ }^{1}$, et al.,

significant average values for all yield characters of squash fruits were derived from untreated plants compare to treated plants during both seasons. The highest average values for number of fruits per plant character were obtained from the combined treatment of $2 \mathrm{mM}$ SA plus $8.5 \mathrm{mM}$ potassium silicate as 14.00 , during both seasons of the study. While treating the plants with $1 \mathrm{mM}$ of salicylic acid in combination with $17 \mathrm{mM}$ potassium silicate (without significance differences with the other treatments); brought about the highest average values for fruit's fresh weight character $(184.00 \mathrm{~g})$ during the first season, but the combined treatment of $3 \mathrm{mM}$ SA plus $8.5 \mathrm{mM}$ potassium silicate; recorded the highest average value (206.67 g) during the second season. With respect to fruit dry weight character, the combination of $1 \mathrm{mM} \mathrm{SA}$ plus $34 \mathrm{mM}$ potassium silicate; showed the highest average values during both seasons as 16.21 and $13.33 \mathrm{~g}$, each in turn. In terms of early yield per plant character, the gained results showed that plants treated with $1 \mathrm{mM}$ SA in combination with $17 \mathrm{mM}$ potassium silicate; resulted in the highest average values during both seasons as 758.33 and $760.00 \mathrm{~g}$, in succession, in addition to plants treated with $2 \mathrm{mM}$ SA (as $763.33 \mathrm{~g}$ ) during the second season only. Regards early fruit yield per feddan, plants sprayed with $1 \mathrm{mM} \mathrm{SA}$ mixed with $17 \mathrm{mM}$ potassium silicate, led to the highest average values during the first and second seasons as 6370.00 and $6384.00(\mathrm{~kg})$, and $2 \mathrm{mM}$ of (SA) or $3 \mathrm{mM}$ (SA) plus $8.5 \mathrm{mM}\left(\mathrm{K}_{2} \mathrm{SiO}_{4}\right)$ which recorded the highest average values of the fruit yield per plant and per feddan during both seasons, consecutively. In the present study, increasing of squash fruit yield was achieved due to foliar application with SA and potassium silicate and their combinations might be attributed to the increase of vegetative growth parameters as reported earlier. The present results are in agreement with those obtained by (Elwan and EL-Shatoury, 2014; Abd El-Mageed et al., 2016; Rubaye and Atia, 2016) who found that exogenously applied SA; increased the highest squash yield/ plant and total yield/hectare compare to the other tested concentrations. Omar (2017) illustrated that foliar application of SA at $200 \mathrm{ppm}$ caused a significant increase readily cucumber early and total fruit yield compared to control plants.

Fayoum J. Agric. Res. \& Dev., Vol. 33, No.1, January, 2019 
Table (4): Averages of some flowering characters of squash plants as affected by foliar application with salicylic acid, potassium silicate and their combinations during the summer seasons of 2016 and 2017.

\begin{tabular}{|c|c|c|c|c|c|}
\hline \multirow{2}{*}{\multicolumn{2}{|c|}{ Treatments }} & \multicolumn{2}{|c|}{ No. of flowers/plant } & \multicolumn{2}{|c|}{$\begin{array}{c}\text { Fruit setting } \\
\text { percentage }\end{array}$} \\
\hline & & 2016 & 2017 & 2016 & 2017 \\
\hline $1-$ & Control & $10.00 \mathrm{~d}$ & $12.67 \mathrm{~d}$ & $83.00 \mathrm{a}-\mathrm{c}$ & $76.00 \mathrm{a}$ \\
\hline $2-$ & $1 \mathrm{mM}(\mathrm{SA})$ & $15.67 \mathrm{a}-\mathrm{c}$ & $15.67 \mathrm{a}-\mathrm{c}$ & $78.67 \mathrm{a}-\mathrm{c}$ & $81.00 \mathrm{a}$ \\
\hline $3-$ & $2 \mathrm{mM}(\mathrm{SA})$ & $15.33 \mathrm{a}-\mathrm{c}$ & $15.67 \mathrm{a}-\mathrm{c}$ & $76.33 \mathrm{c}$ & $79.33 \mathrm{a}$ \\
\hline 4- & $3 \mathrm{mM}(\mathrm{SA})$ & $16.00 \mathrm{a}-\mathrm{c}$ & $15.67 \mathrm{a}-\mathrm{c}$ & $78.33 \mathrm{a}-\mathrm{c}$ & $80.67 \mathrm{a}$ \\
\hline $5-$ & $4.25 \mathrm{mM}\left(\mathrm{K}_{2} \mathrm{SiO}_{3}\right)$ & $15.67 \mathrm{a}-\mathrm{c}$ & $15.33 \mathrm{bc}$ & $83.33 \mathrm{a}-\mathrm{c}$ & $82.67 \mathrm{a}$ \\
\hline $6-$ & $8.5 \mathrm{mM}\left(\mathrm{K}_{2} \mathrm{SiO}_{3}\right)$ & $15.67 \mathrm{a}-\mathrm{c}$ & $16.00 \mathrm{a}-\mathrm{c}$ & $80.67 \mathrm{a}-\mathrm{c}$ & $77.67 \mathrm{a}$ \\
\hline $7-$ & $17 \mathrm{mM}\left(\mathrm{K}_{2} \mathrm{SiO}_{3}\right)$ & $16.67 \mathrm{a}$ & $16.00 \mathrm{a}-\mathrm{c}$ & $77.67 \mathrm{a}-\mathrm{c}$ & $81.33 \mathrm{a}$ \\
\hline $8-$ & $34 \mathrm{mM}\left(\mathrm{K}_{2} \mathrm{SiO}_{3}\right)$ & $16.67 \mathrm{a}$ & $16.00 \mathrm{a}-\mathrm{c}$ & $77.67 \mathrm{a}-\mathrm{c}$ & $75.33 \mathrm{a}$ \\
\hline $9-$ & $1 \mathrm{mM}(\mathrm{SA})+4.25 \mathrm{mM}\left(\mathrm{K}_{2} \mathrm{SiO}_{3}\right)$ & $16.00 \mathrm{a}-\mathrm{c}$ & $15.67 \mathrm{a}-\mathrm{c}$ & $76.67 \mathrm{c}$ & $76.33 \mathrm{a}$ \\
\hline $10-$ & $1 \mathrm{mM}(\mathrm{SA})+8.5 \mathrm{mM}\left(\mathrm{K}_{2} \mathrm{SiO}_{3}\right)$ & $15.00 \mathrm{bc}$ & $15.00 \mathrm{c}$ & $75.33 \mathrm{c}$ & $73.67 \mathrm{a}$ \\
\hline $11-$ & $1 \mathrm{mM}(\mathrm{SA})+17 \mathrm{mM}\left(\mathrm{K}_{2} \mathrm{SiO}_{3}\right)$ & $16.33 \mathrm{ab}$ & $16.00 \mathrm{a}-\mathrm{c}$ & $77.33 \mathrm{bc}$ & $80.00 \mathrm{a}$ \\
\hline $12-$ & $1 \mathrm{mM}(\mathrm{SA})+34 \mathrm{mM}\left(\mathrm{K}_{2} \mathrm{SiO}_{3}\right)$ & $14.67 \mathrm{c}$ & $15.33 \mathrm{bc}$ & $79.67 \mathrm{a}-\mathrm{c}$ & $78.67 \mathrm{a}$ \\
\hline 13- & $2 \mathrm{mM}(\mathrm{SA})+4.25 \mathrm{mM}\left(\mathrm{K}_{2} \mathrm{SiO}_{3}\right)$ & $16.33 \mathrm{ab}$ & $16.00 \mathrm{a}-\mathrm{c}$ & $77.33 \mathrm{bc}$ & $79.00 \mathrm{a}$ \\
\hline $14-$ & $2 \mathrm{mM}(\mathrm{SA})+8.5 \mathrm{mM}\left(\mathrm{K}_{2} \mathrm{SiO}_{3}\right)$ & $16.67 \mathrm{a}$ & $17.00 \mathrm{a}$ & $84.00 \mathrm{a}-\mathrm{c}$ & $82.00 \mathrm{a}$ \\
\hline $15-$ & $2 \mathrm{mM}(\mathrm{SA})+17 \mathrm{mM}\left(\mathrm{K}_{2} \mathrm{SiO}_{3}\right)$ & $15.67 \mathrm{a}-\mathrm{c}$ & $16.67 \mathrm{ab}$ & $87.33 \mathrm{a}$ & $80.67 \mathrm{a}$ \\
\hline $16-$ & $2 \mathrm{mM}(\mathrm{SA})+34 \mathrm{mM}\left(\mathrm{K}_{2} \mathrm{SiO}_{3}\right)$ & $15.33 \mathrm{a}-\mathrm{c}$ & $16.00 \mathrm{a}-\mathrm{c}$ & $82.33 \mathrm{a}-\mathrm{c}$ & $79.33 \mathrm{a}$ \\
\hline $17-$ & $3 \mathrm{mM}(\mathrm{SA})+4.24 \mathrm{mM}\left(\mathrm{K}_{2} \mathrm{SiO}_{3}\right)$ & $15.00 \mathrm{bc}$ & $16.33 \mathrm{a}-\mathrm{c}$ & $87.00 \mathrm{ab}$ & $73.67 \mathrm{a}$ \\
\hline $18-$ & $3 \mathrm{mM}(\mathrm{SA})+8.5 \mathrm{mM}\left(\mathrm{K}_{2} \mathrm{SiO}_{3}\right)$ & $15.00 \mathrm{bc}$ & $15.33 \mathrm{bc}$ & $86.67 \mathrm{ab}$ & $80.33 \mathrm{a}$ \\
\hline 19- & $3 \mathrm{mM}(\mathrm{SA})+17 \mathrm{mM}\left(\mathrm{K}_{2} \mathrm{SiO}_{3}\right)$ & $15.33 \mathrm{a}-\mathrm{c}$ & $16.33 \mathrm{a}-\mathrm{c}$ & $82.33 \mathrm{a}-\mathrm{c}$ & $71.33 \mathrm{a}$ \\
\hline $20-$ & $3 \mathrm{mM}(\mathrm{SA})+34 \mathrm{mM}\left(\mathrm{K}_{2} \mathrm{SiO}_{3}\right)$ & $15.33 \mathrm{a}-\mathrm{c}$ & $16.00 \mathrm{a}-\mathrm{c}$ & $80.33 \mathrm{a}-\mathrm{c}$ & $83.33 \mathrm{a}$ \\
\hline
\end{tabular}

- SA, salicylic acid; $\mathrm{K}_{2} \mathrm{SiO}_{3}$, potassium silicate.

- Values having the same alphabetical letter (s) in common, within each column, do not significantly differ, using the revised L.S.D. test at 0.05 level of probability.

Fayoum J. Agric. Res. \& Dev., Vol. 33, No.1, January, 2019 
Abd-Elaziz. S. A' , et al.,

Table (5): Averages of some yield characters of squash fruits as affected by foliar application with salicylic acid, potassium silicate and their combinations during the summer seasons of 2016 and 2017.

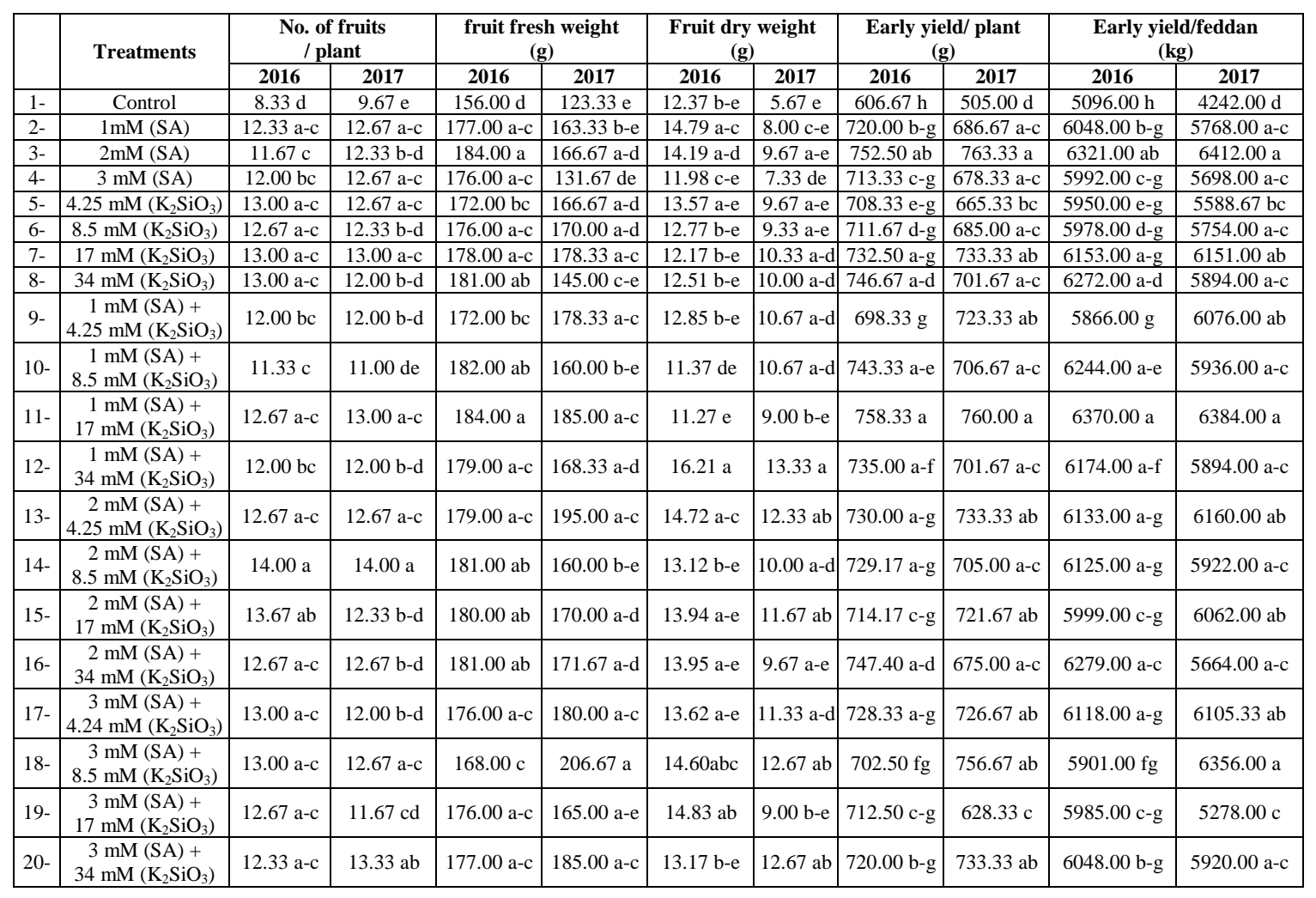

- SA, salicylic acid; $\mathrm{K}_{2} \mathrm{SiO}_{3}$, potassium silicate.

- Values having the same alphabetical letter (s) in common, within each column, do not significantly differ, using the revised L.S.D. test at 0.05 level of probability.

Fayoum J. Agric. Res. \& Dev., Vol. 33, No.1, January, 2019 
Table (6): Averages of some yield characters of squash fruits as affected by foliar application with salicylic acid, potassium silicate and their combinations during the summer seasons of 2016 and 2017.

\begin{tabular}{|c|c|c|c|c|c|}
\hline & \multirow[t]{2}{*}{ Treatments } & \multicolumn{2}{|c|}{$\begin{array}{c}\text { Fruit yield/ plant } \\
(\mathrm{kg})\end{array}$} & \multicolumn{2}{|c|}{$\begin{array}{c}\text { Fruit yield/feddan } \\
\text { (ton) }\end{array}$} \\
\hline & & 2016 & 2017 & 2016 & 2017 \\
\hline $1-$ & Control & $1.30 \mathrm{e}$ & $1.20 \mathrm{~b}$ & $10.93 \mathrm{~d}$ & $10.07 \mathrm{e}$ \\
\hline $2-$ & $1 \mathrm{mM}(\mathrm{SA})$ & $2.18 \mathrm{~b}-\mathrm{d}$ & $1.97 \mathrm{~b}$ & $18.34 \mathrm{bc}$ & $16.58 \mathrm{a}-\mathrm{d}$ \\
\hline $3-$ & $2 \mathrm{mM}(\mathrm{SA})$ & $2.15 \mathrm{~cd}$ & $2.06 \mathrm{~b}$ & $18.03 \mathrm{c}$ & $17.32 \mathrm{a}-\mathrm{d}$ \\
\hline 4- & $3 \mathrm{mM}(\mathrm{SA})$ & $2.11 \mathrm{~cd}$ & $1.68 \mathrm{~b}$ & $17.74 \mathrm{c}$ & $14.07 \mathrm{de}$ \\
\hline $5-$ & $4.25 \mathrm{mM}\left(\mathrm{K}_{2} \mathrm{SiO}_{3}\right)$ & $2.28 \mathrm{a}-\mathrm{d}$ & $1.87 \mathrm{~b}$ & $19.12 \mathrm{a}-\mathrm{c}$ & $15.67 \mathrm{~b}-\mathrm{d}$ \\
\hline $6-$ & $8.5 \mathrm{mM}\left(\mathrm{K}_{2} \mathrm{SiO}_{3}\right)$ & $2.23 \mathrm{~b}-\mathrm{d}$ & $2.09 \mathrm{~b}$ & $18.73 \mathrm{a}-\mathrm{c}$ & $17.58 \mathrm{a}-\mathrm{d}$ \\
\hline $7-$ & $17 \mathrm{mM}\left(\mathrm{K}_{2} \mathrm{SiO}_{3}\right)$ & $2.31 \mathrm{a}-\mathrm{d}$ & $2.32 \mathrm{~b}$ & $19.44 \mathrm{a}-\mathrm{c}$ & 19.47 a-d \\
\hline 8- & $34 \mathrm{mM}\left(\mathrm{K}_{2} \mathrm{SiO}_{3}\right)$ & $2.35 \mathrm{a}-\mathrm{c}$ & $1.74 \mathrm{~b}$ & $19.76 \mathrm{a}-\mathrm{c}$ & $14.62 \mathrm{de}$ \\
\hline 9- & $1 \mathrm{mM}(\mathrm{SA})+4.25 \mathrm{mM}\left(\mathrm{K}_{2} \mathrm{SiO}_{3}\right)$ & $2.06 \mathrm{~d}$ & $2.12 \mathrm{~b}$ & $17.30 \mathrm{c}$ & $17.95 \mathrm{a}-\mathrm{d}$ \\
\hline $10-$ & $1 \mathrm{mM}(\mathrm{SA})+8.5 \mathrm{mM}\left(\mathrm{K}_{2} \mathrm{SiO}_{3}\right)$ & $2.06 \mathrm{~d}$ & $1.75 \mathrm{~b}$ & $17.33 \mathrm{c}$ & $14.76 \mathrm{c}-\mathrm{e}$ \\
\hline $11-$ & $1 \mathrm{mM}(\mathrm{SA})+17 \mathrm{mM}\left(\mathrm{K}_{2} \mathrm{SiO}_{3}\right)$ & $2.27 \mathrm{a}-\mathrm{d}$ & $2.41 \mathrm{~b}$ & $19.06 \mathrm{a}-\mathrm{c}$ & $20.19 \mathrm{a}-\mathrm{c}$ \\
\hline $12-$ & $1 \mathrm{mM}(\mathrm{SA})+34 \mathrm{mM}\left(\mathrm{K}_{2} \mathrm{SiO}_{3}\right)$ & $2.15 \mathrm{~cd}$ & $2.01 \mathrm{~b}$ & $18.05 \mathrm{c}$ & $16.90 \mathrm{a}-\mathrm{d}$ \\
\hline $13-$ & $2 \mathrm{mM}(\mathrm{SA})+4.25 \mathrm{mM}\left(\mathrm{K}_{2} \mathrm{SiO}_{3}\right)$ & $2.27 \mathrm{a}-\mathrm{d}$ & $2.47 \mathrm{~b}$ & $19.03 \mathrm{a}-\mathrm{c}$ & $20.76 \mathrm{ab}$ \\
\hline $14-$ & $2 \mathrm{mM}(\mathrm{SA})+8.5 \mathrm{mM}\left(\mathrm{K}_{2} \mathrm{SiO}_{3}\right)$ & $2.53 \mathrm{a}$ & $3.07 \mathrm{a}$ & $21.28 \mathrm{a}$ & $18.80 \mathrm{a}-\mathrm{d}$ \\
\hline $15-$ & $2 \mathrm{mM}(\mathrm{SA})+17 \mathrm{mM}\left(\mathrm{K}_{2} \mathrm{SiO}_{3}\right)$ & $2.46 \mathrm{ab}$ & $2.11 \mathrm{~b}$ & $20.68 \mathrm{ab}$ & $17.68 \mathrm{a}-\mathrm{d}$ \\
\hline $16-$ & $2 \mathrm{mM}(\mathrm{SA})+34 \mathrm{mM}\left(\mathrm{K}_{2} \mathrm{SiO}_{3}\right)$ & $2.19 \mathrm{~b}-\mathrm{d}$ & $2.18 \mathrm{~b}$ & $19.21 \mathrm{a}-\mathrm{c}$ & $18.41 \mathrm{a}-\mathrm{d}$ \\
\hline $17-$ & $3 \mathrm{mM}(\mathrm{SA})+4.24 \mathrm{mM}\left(\mathrm{K}_{2} \mathrm{SiO}_{3}\right)$ & $2.29 \mathrm{a}-\mathrm{d}$ & $2.15 \mathrm{~b}$ & $19.22 \mathrm{a}-\mathrm{c}$ & 18.06 a-d \\
\hline $18-$ & $3 \mathrm{mM}(\mathrm{SA})+8.5 \mathrm{mM}\left(\mathrm{K}_{2} \mathrm{SiO}_{3}\right)$ & $2.17 \mathrm{~cd}$ & $2.62 \mathrm{~b}$ & $18.19 \mathrm{bc}$ & $21.97 \mathrm{a}$ \\
\hline $19-$ & $3 \mathrm{mM}(\mathrm{SA})+17 \mathrm{mM}\left(\mathrm{K}_{2} \mathrm{SiO}_{3}\right)$ & $2.22 \mathrm{~b}-\mathrm{d}$ & $2.56 \mathrm{~b}$ & $18.62 \mathrm{bc}$ & $15.90 \mathrm{~b}-\mathrm{d}$ \\
\hline $20-$ & $3 \mathrm{mM}(\mathrm{SA})+34 \mathrm{mM}\left(\mathrm{K}_{2} \mathrm{SiO}_{3}\right)$ & $2.18 \mathrm{~b}-\mathrm{d}$ & $2.19 \mathrm{~b}$ & $18.34 \mathrm{bc}$ & $18.40 \mathrm{a}-\mathrm{d}$ \\
\hline
\end{tabular}

- SA, salicylic acid; $\mathrm{K}_{2} \mathrm{SiO}_{3}$, potassium silicate.

- Values having the same alphabetical letter (s) in common, within each column, do not significantly differ, using the revised L.S.D. test at 0.05 level of probability.

Fayoum J. Agric. Res. \& Dev., Vol. 33, No.1, January, 2019 
Abd-Elaziz. S. $A^{1}$., et al.,

Respecting Si application, the postulated results agree, also, with those obtained by Omar (2017) who illustrated that foliar application of Si at $100 \mathrm{ppm}$ caused; significant increase on cucumber fruit yield compared to control plants. Matichenkov and Bocharnikova (2008) found that cucumber yield was increased, significantly either by foliar silicon with $10 \mathrm{~kg} \mathrm{ha}^{-1}$ at the $3^{\text {rd }}$ leaf stage and subsequent bi-weekly applications during the season or by soil $\mathrm{Si}$ applications $\left(40 \mathrm{~kg} \mathrm{ha}^{-1}\right)$. There are additional benefits for $\mathrm{Si}$ include stimulation of fruit formation and accelerated fruit maturation. Also, Buttaro et al. (2009) illustrated that fruit fresh and dry weights of melon were not affected by root application of $\mathrm{Si}$.

\section{Fruit quality's characters}

\subsection{Fruit length, diameter and shape index}

Results postulated in Table (7) reveal that all treated plants showed the highest significant average values of fruit length and fruit diameter characters compared to untreated plants during both seasons. However, plants that treated with $2 \mathrm{mM}$ SA singly or $1 \mathrm{mM}$ combined with $17 \mathrm{mM}$ potassium silicate, led to the highest average values for fruit length as $17.00 \mathrm{and} / \mathrm{or} 16.33 \mathrm{~cm}$ during both seasons, respectively. In addition, plants treated with $2 \mathrm{mM}$ salicylic acid mixed with 4.25 or 8.5 or $34 \mathrm{mM}$ potassium silicate recorded higher average values of the given trait compare to control treatment as 14.00 or $13.83 \mathrm{~cm}$ during both seasons. Concerning the fruit diameter character, plants sprayed with potassium silicate at either $17 \mathrm{mM}$ or $34 \mathrm{mM}$ or the combination between $1 \mathrm{mM}(\mathrm{SA})+34$ $\mathrm{mM}\left(\mathrm{K}_{2} \mathrm{SiO}_{3}\right)$ brought about, significantly, higher average values of the given trait as $4.20,4.17,4.17$ and $4.14 \mathrm{~cm}$, each in turn, compare to the control plants $(3.43 \mathrm{~cm})$, during the first season. During the second season, the combination between $1 \mathrm{mM}(\mathrm{SA})+34 \mathrm{mM}\left(\mathrm{K}_{2} \mathrm{SiO}_{3}\right)$, caused, significantly, high average value $(4.07 \mathrm{~cm})$ compare to the control treatment $(3.07 \mathrm{~cm})$. In terms of fruit shape index, during the first season the highest average values were obtained from plants sprayed with $3 \mathrm{mM}$ salicylic acid or $4.25 \mathrm{mM}$ potassium silicate (4.19 and 4.21) or due to the combination between $1 \mathrm{mM} \mathrm{SA}$ and $17 \mathrm{mM}$ potassium silicate or $2 \mathrm{mM}$ salicylic acid combined with $4.25 \mathrm{mM}$ potassium silicate as 4.21 compare to the combination treatment of $1 \mathrm{mM}(\mathrm{SA})+4.25 \mathrm{mM}$ $\left(\mathrm{K}_{2} \mathrm{SiO}_{3}\right)$ as 3.76. While in the second season, nonsignificant effects were showed among all treatments. These results are in agreement with those illustrated by Omar (2017) who indicated that foliar application with either SA at $200 \mathrm{ppm}$ or Si at $100 \mathrm{ppm}$; resulted in significant increase in fruit length and diameter of cucumber compared to control plants.

Fayoum J. Agric. Res. \& Dev., Vol. 33, No.1, January, 2019 
Table (7): Averages of fruit length, diameter and shape index characters of squash as affected by foliar application with salicylic acid, potassium silicate and their combinations during the summer seasons of 2016 and 2017.

\begin{tabular}{|c|c|c|c|c|c|c|c|}
\hline & \multirow{2}{*}{ Treatments } & \multicolumn{2}{|c|}{ Fruit length $(\mathrm{cm})$} & \multicolumn{2}{|c|}{ Fruit diameter $(\mathrm{cm})$} & \multicolumn{2}{|c|}{ Fruit shape index } \\
\hline & & 2016 & 2017 & 2016 & 2017 & 2016 & 2017 \\
\hline $1-$ & Control & $14.00 \mathrm{c}$ & $13.83 \mathrm{c}$ & $3.43 \mathrm{c}$ & $3.07 \mathrm{e}$ & $4.12 \mathrm{ab}$ & $4.44 \mathrm{a}$ \\
\hline $2-$ & $1 \mathrm{mM}(\mathrm{SA})$ & $16.00 \mathrm{ab}$ & $16.00 \mathrm{ab}$ & $3.83 \mathrm{~b}$ & $3.73 \mathrm{~cd}$ & $4.16 \mathrm{ab}$ & $4.29 \mathrm{a}$ \\
\hline $3-$ & $2 \mathrm{mM}(\mathrm{SA})$ & $17.00 \mathrm{a}$ & $16.33 \mathrm{a}$ & $4.10 \mathrm{ab}$ & $3.87 \mathrm{a}-\mathrm{d}$ & $4.17 \mathrm{ab}$ & $4.23 \mathrm{a}$ \\
\hline 4- & $3 \mathrm{mM}(\mathrm{SA})$ & $16.00 \mathrm{ab}$ & $15.67 \mathrm{ab}$ & $3.80 \mathrm{~b}$ & $3.63 \mathrm{~d}$ & $4.19 \mathrm{a}$ & $4.31 \mathrm{a}$ \\
\hline $5-$ & $4.25 \mathrm{mM}\left(\mathrm{K}_{2} \mathrm{SiO}_{3}\right)$ & $16.00 \mathrm{ab}$ & $15.50 \mathrm{ab}$ & $3.80 \mathrm{~b}$ & $3.77 \mathrm{~b}-\mathrm{d}$ & $4.21 \mathrm{a}$ & $4.11 \mathrm{a}$ \\
\hline $6-$ & $8.5 \mathrm{mM}\left(\mathrm{K}_{2} \mathrm{SiO}_{3}\right)$ & $16.00 \mathrm{ab}$ & $15.00 \mathrm{~b}$ & $4.00 \mathrm{ab}$ & $3.80 \mathrm{a}-\mathrm{d}$ & $4.02 \mathrm{a}-\mathrm{c}$ & $3.95 \mathrm{a}$ \\
\hline $7-$ & $17 \mathrm{mM}\left(\mathrm{K}_{2} \mathrm{SiO}_{3}\right)$ & $16.00 \mathrm{ab}$ & $16.00 \mathrm{ab}$ & $4.20 \mathrm{a}$ & $4.00 \mathrm{a}-\mathrm{c}$ & $3.92 \mathrm{a}-\mathrm{c}$ & $3.99 \mathrm{a}$ \\
\hline $8-$ & $34 \mathrm{mM}\left(\mathrm{K}_{2} \mathrm{SiO}_{3}\right)$ & $17.00 \mathrm{ab}$ & $16.00 \mathrm{ab}$ & $4.17 \mathrm{a}$ & $3.93 \mathrm{a}-\mathrm{c}$ & $3.92 \mathrm{a}-\mathrm{c}$ & $4.07 \mathrm{a}$ \\
\hline $9-$ & $1 \mathrm{mM}(\mathrm{SA})+4.25 \mathrm{mM}\left(\mathrm{K}_{2} \mathrm{SiO}_{3}\right)$ & $15.00 \mathrm{bc}$ & $16.00 \mathrm{ab}$ & $3.95 \mathrm{ab}$ & $3.80 \mathrm{a}-\mathrm{d}$ & $3.76 \mathrm{c}$ & $4.23 \mathrm{a}$ \\
\hline $10-$ & $1 \mathrm{mM}(\mathrm{SA})+8.5 \mathrm{mM}\left(\mathrm{K}_{2} \mathrm{SiO}_{3}\right)$ & $16.00 \mathrm{ab}$ & $16.00 \mathrm{ab}$ & $4.00 \mathrm{ab}$ & $3.87 \mathrm{a}-\mathrm{d}$ & $4.04 \mathrm{a}-\mathrm{c}$ & $4.15 \mathrm{a}$ \\
\hline 11- & $1 \mathrm{mM}(\mathrm{SA})+17 \mathrm{mM}\left(\mathrm{K}_{2} \mathrm{SiO}_{3}\right)$ & $17.00 \mathrm{a}$ & $16.33 \mathrm{a}$ & $4.07 \mathrm{ab}$ & $4.03 \mathrm{ab}$ & $4.21 \mathrm{a}$ & $4.05 \mathrm{a}$ \\
\hline $12-$ & $1 \mathrm{mM}(\mathrm{SA})+34 \mathrm{mM}\left(\mathrm{K}_{2} \mathrm{SiO}_{3}\right)$ & $16.00 \mathrm{ab}$ & $16.00 \mathrm{ab}$ & $4.17 \mathrm{a}$ & $4.07 \mathrm{a}$ & $3.84 \mathrm{bc}$ & $3.93 \mathrm{a}$ \\
\hline 13- & $2 \mathrm{mM}(\mathrm{SA})+4.25 \mathrm{mM}\left(\mathrm{K}_{2} \mathrm{SiO}_{3}\right)$ & $16.00 \mathrm{ab}$ & $16.50 \mathrm{a}$ & $3.80 \mathrm{~b}$ & $3.90 \mathrm{a}-\mathrm{d}$ & $4.21 \mathrm{a}$ & $4.23 \mathrm{a}$ \\
\hline 14- & $2 \mathrm{mM}(\mathrm{SA})+8.5 \mathrm{mM}\left(\mathrm{K}_{2} \mathrm{SiO}_{3}\right)$ & $16.00 \mathrm{ab}$ & $16.17 \mathrm{a}$ & $3.93 \mathrm{ab}$ & $3.90 \mathrm{a}-\mathrm{d}$ & $4.16 \mathrm{ab}$ & $4.14 \mathrm{a}$ \\
\hline $15-$ & $2 \mathrm{mM}(\mathrm{SA})+17 \mathrm{mM}\left(\mathrm{K}_{2} \mathrm{SiO}_{3}\right)$ & $16.00 \mathrm{ab}$ & $16.00 \mathrm{ab}$ & $4.17 \mathrm{a}$ & $3.97 \mathrm{a}-\mathrm{c}$ & $3.76 \mathrm{c}$ & $4.01 \mathrm{a}$ \\
\hline $16-$ & $2 \mathrm{mM}(\mathrm{SA})+34 \mathrm{mM}\left(\mathrm{K}_{2} \mathrm{SiO}_{3}\right)$ & $16.00 \mathrm{ab}$ & $16.50 \mathrm{a}$ & $4.00 \mathrm{ab}$ & $3.87 \mathrm{a}-\mathrm{d}$ & $4.14 \mathrm{ab}$ & $4.27 \mathrm{a}$ \\
\hline $17-$ & $3 \mathrm{mM}(\mathrm{SA})+4.24 \mathrm{mM}\left(\mathrm{K}_{2} \mathrm{SiO}_{3}\right)$ & $16.00 \mathrm{ab}$ & $16.00 \mathrm{ab}$ & $3.97 \mathrm{ab}$ & $3.97 \mathrm{a}-\mathrm{c}$ & $4.01 \mathrm{a}-\mathrm{c}$ & $4.04 \mathrm{a}$ \\
\hline $18-$ & $3 \mathrm{mM}(\mathrm{SA})+8.5 \mathrm{mM}\left(\mathrm{K}_{2} \mathrm{SiO}_{3}\right)$ & $15.00 \mathrm{bc}$ & $16.00 \mathrm{ab}$ & $3.93 \mathrm{ab}$ & $3.83 \mathrm{a}-\mathrm{d}$ & $4.03 \mathrm{a}-\mathrm{c}$ & $4.17 \mathrm{a}$ \\
\hline 19- & $3 \mathrm{mM}(\mathrm{SA})+17 \mathrm{mM}\left(\mathrm{K}_{2} \mathrm{SiO}_{3}\right)$ & $15.00 \mathrm{bc}$ & $15.50 \mathrm{ab}$ & $3.83 \mathrm{~b}$ & $3.73 \mathrm{~cd}$ & $3.95 \mathrm{a}-\mathrm{c}$ & $4.12 \mathrm{a}$ \\
\hline $20-$ & $3 \mathrm{mM}(\mathrm{SA})+34 \mathrm{mM}\left(\mathrm{K}_{2} \mathrm{SiO}_{3}\right)$ & $16.00 \mathrm{ab}$ & $16.00 \mathrm{ab}$ & $3.93 \mathrm{ab}$ & $3.87 \mathrm{a}-\mathrm{d}$ & $4.14 \mathrm{ab}$ & $4.14 \mathrm{a}$ \\
\hline
\end{tabular}

-SA, salicylic acid; $\mathrm{K}_{2} \mathrm{SiO}_{3}$, potassium silicates. Values having the same alphabetical letter (s) in common, within each column, do not significantly differ, using the revised L.S.D. test at 0.05 level of probability.

\subsection{Fruits titratable acidity and TSS\%}

Results of Table (8) divulged that the lowest average values of acidity character (5.20 and $4.03 \%$, respectively) were found from untreated plants during both seasons. While, the highest average values (5.94 and 5.59\%, orderly) were obtained from plants treated with $2 \mathrm{mM}$ salicylic acid during both seasons compare to all other treatments. Results also revealed that the lowest Brix values of fruit TSS were recorded during both seasons from control plants as 4.87 and $4.10 \%$, in succession, compare to the other treatments. The highest values (6.00 Brix) were gained from the plants sprayed with $2 \mathrm{mM}$ SA or $1 \mathrm{mM}$ SA combined with $17 \mathrm{mM}$ potassium silicate during the second season. While during the first season, nonsignificant effects were found among all treatments excepted untreated plants which gave the lowest significant values. The obtained results are in parallel with those reported by Omar (2017) who illustrated that foliar application of either SA at $200 \mathrm{ppm}$ or Si at $100 \mathrm{ppm}$ caused; significant increase in TSS of cucumber fruits compared to control

Fayoum J. Agric. Res. \& Dev., Vol. 33, No.1, January, 2019 
Abd-Elaziz. S. $A^{1}$., et al.,

plants. AL-Rubaye and Atia (2016) illustrated that the highest total soluble solids of carbohydrates of squash fruits were found to be due to applying $\mathrm{Si}$ at $5 \mathrm{mM}$ concentration compared with the other concentration. Furthermore, Kazemi (2014) found that total soluble solids and titratable acidity content of tomato fruit had, significantly, affected by the application of salicylic acid. On the other hand, Buttaro et al. (2009) illustrated that fruit TSS and titratable acidity of melon were not affected by root application of Si. Also, Jayawardana et al. (2014) on pepper reported that titratable acidity was not affected by Si application.

\subsection{Fruits' reducing, non-reducing and total sugars}

Results of Table (9) demonstrated that untreated plants (control) provided the lowest percent values for reducing and total sugars as 1.217 and $1.754 \%$ for the former and 1.725 and 2.072 for the later during both seasons. Meanwhile, untreated (control) plants, gave rise to the highest percent value for non-reducing sugars character as $0.508 \%$ during first season, while the lowest percent value was obtained from plants treated with $1 \mathrm{mM}$ SA as $0.208 \%$. Treatments showed nonsignificant effect on non-reducing sugars character during second season. Data, also, showed that foliar application of $34 \mathrm{mM}$ potassium silicate; gave rise to the highest percent value of reducing sugars as $5.384 \%$ during the first season, but during the second one nonsignificant effects were found among treatments of salicylic, potassium silicate and their combination. Concerning total sugars character, treatments of either $2 \mathrm{mM} \mathrm{SA}$ or $17 \mathrm{mM}$ potassium silicate or combination $3 \mathrm{mM}$ SA plus $34 \mathrm{mM}$ potassium silicate accompanied by the highest percent values during the first season as 5.290 or $4.778 \%$, respectively, compare to control treatments. While during the second season nonsignificant effects were found among SA, potassium silicate and their combination on total sugars character.

Fayoum J. Agric. Res. \& Dev., Vol. 33, No.1, January, 2019 
EFFECT OF FOLIAR APPLICATION WITH SALICYLIC ACID

Table (8): Averages of acidity and total soluble solids characters of squash fruits as affected by foliar application with salicylic acid, potassium silicate and their combinations during the summer seasons of 2016 and 2017.

\begin{tabular}{|c|c|c|c|c|c|}
\hline & \multirow{2}{*}{ Treatments } & \multicolumn{2}{|c|}{ Acidity \% } & \multicolumn{2}{|c|}{ TSS \% ( Brix) } \\
\hline & & 2016 & 2017 & 2016 & 2017 \\
\hline $1-$ & Control & $5.20 \mathrm{~b}$ & $4.03 \mathrm{~h}$ & $4.87 \mathrm{~b}$ & $4.10 \mathrm{~g}$ \\
\hline $2-$ & $1 \mathrm{mM}(\mathrm{SA})$ & $6.16 \mathrm{a}$ & $4.78 \mathrm{c}-\mathrm{f}$ & $6.33 \mathrm{a}$ & $5.27 \mathrm{c}-\mathrm{e}$ \\
\hline $3-$ & $2 \mathrm{mM}(\mathrm{SA})$ & $5.94 \mathrm{a}$ & $5.59 \mathrm{a}$ & $6.20 \mathrm{a}$ & $6.00 \mathrm{a}$ \\
\hline $4-$ & $3 \mathrm{mM}(\mathrm{SA})$ & $5.66 \mathrm{ab}$ & $4.40 \mathrm{e}-\mathrm{h}$ & $6.20 \mathrm{a}$ & $5.33 \mathrm{~b}-\mathrm{d}$ \\
\hline $5-$ & $4.25 \mathrm{mM}\left(\mathrm{K}_{2} \mathrm{SiO}_{3}\right)$ & $5.87 \mathrm{a}$ & $4.19 \mathrm{gh}$ & $6.17 \mathrm{a}$ & $5.00 \mathrm{~d}-\mathrm{f}$ \\
\hline $6-$ & $8.5 \mathrm{mM}\left(\mathrm{K}_{2} \mathrm{SiO}_{3}\right)$ & $5.81 \mathrm{a}$ & $5.30 \mathrm{ab}$ & $5.93 \mathrm{a}$ & $4.73 \mathrm{f}$ \\
\hline $7-$ & $17 \mathrm{mM}\left(\mathrm{K}_{2} \mathrm{SiO}_{3}\right)$ & $5.93 \mathrm{a}$ & $4.83 \mathrm{~b}-\mathrm{e}$ & $6.03 \mathrm{a}$ & $4.80 \mathrm{f}$ \\
\hline $8-$ & $34 \mathrm{mM}\left(\mathrm{K}_{2} \mathrm{SiO}_{3}\right)$ & $6.02 \mathrm{a}$ & $5.10 \mathrm{bc}$ & $6.47 \mathrm{a}$ & $5.10 \mathrm{~d}-\mathrm{f}$ \\
\hline 9- & $1 \mathrm{mM}(\mathrm{SA})+4.25 \mathrm{mM}\left(\mathrm{K}_{2} \mathrm{SiO}_{3}\right)$ & $5.60 \mathrm{ab}$ & $4.19 \mathrm{gh}$ & $6.33 \mathrm{a}$ & 4.90 ef \\
\hline $10-$ & $1 \mathrm{mM}(\mathrm{SA})+8.5 \mathrm{mM}\left(\mathrm{K}_{2} \mathrm{SiO}_{3}\right)$ & $5.87 \mathrm{a}$ & $4.50 \mathrm{~d}-\mathrm{h}$ & $5.90 \mathrm{a}$ & $5.33 \mathrm{~b}-\mathrm{e}$ \\
\hline $11-$ & $1 \mathrm{mM}(\mathrm{SA})+17 \mathrm{mM}\left(\mathrm{K}_{2} \mathrm{SiO}_{3}\right)$ & $6.04 \mathrm{a}$ & $4.96 \mathrm{~b}-\mathrm{d}$ & $6.47 \mathrm{a}$ & $5.97 \mathrm{a}$ \\
\hline $12-$ & $1 \mathrm{mM}(\mathrm{SA})+34 \mathrm{mM}\left(\mathrm{K}_{2} \mathrm{SiO}_{3}\right)$ & $5.97 \mathrm{a}$ & $4.08 \mathrm{~h}$ & $6.30 \mathrm{a}$ & $5.57 \mathrm{a}-\mathrm{c}$ \\
\hline $13-$ & $2 \mathrm{mM}(\mathrm{SA})+4.25 \mathrm{mM}\left(\mathrm{K}_{2} \mathrm{SiO}_{3}\right)$ & $5.86 \mathrm{a}$ & $4.30 \mathrm{gh}$ & $6.23 \mathrm{a}$ & $5.37 \mathrm{~b}-\mathrm{d}$ \\
\hline $14-$ & $2 \mathrm{mM}(\mathrm{SA})+8.5 \mathrm{mM}\left(\mathrm{K}_{2} \mathrm{SiO}_{3}\right)$ & $6.03 \mathrm{a}$ & $4.60 \mathrm{~d}-\mathrm{g}$ & $6.33 \mathrm{a}$ & $5.10 \mathrm{c}-\mathrm{e}$ \\
\hline $15-$ & $2 \mathrm{mM}(\mathrm{SA})+17 \mathrm{mM}\left(\mathrm{K}_{2} \mathrm{SiO}_{3}\right)$ & $6.04 \mathrm{a}$ & $4.12 \mathrm{~h}$ & $6.43 \mathrm{a}$ & $5.43 \mathrm{~b}-\mathrm{d}$ \\
\hline 16- & $2 \mathrm{mM}(\mathrm{SA})+34 \mathrm{mM}\left(\mathrm{K}_{2} \mathrm{SiO}_{3}\right)$ & $5.75 \mathrm{ab}$ & $5.19 \mathrm{a}-\mathrm{c}$ & $6.20 \mathrm{a}$ & $5.67 \mathrm{a}-\mathrm{c}$ \\
\hline $17-$ & $3 \mathrm{mM}(\mathrm{SA})+4.24 \mathrm{mM}\left(\mathrm{K}_{2} \mathrm{SiO}_{3}\right)$ & $5.85 \mathrm{a}$ & $4.11 \mathrm{~h}$ & $6.00 \mathrm{a}$ & $4.77 \mathrm{f}$ \\
\hline $18-$ & $3 \mathrm{mM}(\mathrm{SA})+8.5 \mathrm{mM}\left(\mathrm{K}_{2} \mathrm{SiO}_{3}\right)$ & $5.64 \mathrm{ab}$ & $4.20 \mathrm{gh}$ & $6.17 \mathrm{a}$ & $5.27 \mathrm{c}-\mathrm{e}$ \\
\hline 19- & $3 \mathrm{mM}(\mathrm{SA})+17 \mathrm{mM}\left(\mathrm{K}_{2} \mathrm{SiO}_{3}\right)$ & $5.80 \mathrm{a}$ & $4.46 \mathrm{e}-\mathrm{h}$ & $6.30 \mathrm{a}$ & $5.73 \mathrm{ab}$ \\
\hline $20-$ & $3 \mathrm{mM}(\mathrm{SA})+34 \mathrm{mM}\left(\mathrm{K}_{2} \mathrm{SiO}_{3}\right)$ & $6.16 \mathrm{a}$ & $4.32 \mathrm{f}-\mathrm{h}$ & $6.33 \mathrm{a}$ & $5.70 \mathrm{a}-\mathrm{c}$ \\
\hline
\end{tabular}

-SA, salicylic acid; $\mathrm{K}_{2} \mathrm{SiO}_{3}$, potassium silicates. Values having the same alphabetical letter (s) in common, within each column, do not significantly differ, using the revised L.S.D. test at 0.05 level of probability.

Fayoum J. Agric. Res. \& Dev., Vol. 33, No.1, January, 2019 
Abd-Elaziz. S. $A^{1}$., et al.,

Table (9):Averages of reducing, non-reducing and total sugars characters of squash fruits as affected by foliar application with salicylic acid, potassium silicate and their combinations during the summer seasons of 2016 and 2017.

\begin{tabular}{|c|c|c|c|c|c|c|c|}
\hline & \multirow{3}{*}{ Treatments } & \multicolumn{6}{|c|}{ Fruits sugars (\% DW) } \\
\hline & & \multicolumn{2}{|c|}{ Reducing sugars } & \multicolumn{2}{|c|}{ Non-reducing sugars } & \multicolumn{2}{|c|}{ Total sugars } \\
\hline & & 2016 & 2017 & 2016 & 2017 & 2016 & 2017 \\
\hline $1-$ & Control & $1.217 \mathrm{e}$ & $1.754 \mathrm{~b}$ & $0.508 \mathrm{a}$ & $0.318 \mathrm{a}$ & $1.725 \mathrm{e}$ & $2.072 \mathrm{~b}$ \\
\hline $2-$ & $1 \mathrm{mM}(\mathrm{SA})$ & $1.880 \mathrm{de}$ & $3.111 \mathrm{ab}$ & $0.208 \mathrm{~g}$ & $0.487 \mathrm{a}$ & $2.087 \mathrm{de}$ & $3.598 \mathrm{ab}$ \\
\hline $3-$ & $2 \mathrm{mM}(\mathrm{SA})$ & $4.652 \mathrm{a}-\mathrm{c}$ & $3.864 \mathrm{a}$ & $0.387 \mathrm{a}-\mathrm{f}$ & $0.453 \mathrm{a}$ & $5.290 \mathrm{a}$ & $4.317 \mathrm{a}$ \\
\hline 4- & $3 \mathrm{mM}(\mathrm{SA})$ & $3.409 \mathrm{~b}-\mathrm{d}$ & $3.183 \mathrm{ab}$ & $0.297 \mathrm{c}-\mathrm{g}$ & $0.358 \mathrm{a}$ & 3.806 a-e & $3.541 \mathrm{ab}$ \\
\hline $5-$ & $4.25 \mathrm{mM}\left(\mathrm{K}_{2} \mathrm{SiO}_{3}\right)$ & $4.060 \mathrm{a}-\mathrm{c}$ & $3.592 \mathrm{a}$ & $0.389 \mathrm{a}-\mathrm{f}$ & $0.404 \mathrm{a}$ & $4.449 \mathrm{a}-\mathrm{c}$ & $3.996 \mathrm{a}$ \\
\hline $6-$ & $8.5 \mathrm{mM}\left(\mathrm{K}_{2} \mathrm{SiO}_{3}\right)$ & $4.305 \mathrm{a}-\mathrm{c}$ & $4.060 \mathrm{a}$ & $0.379 \mathrm{a}-\mathrm{f}$ & $0.348 \mathrm{a}$ & $4.684 \mathrm{a}-\mathrm{c}$ & $4.454 \mathrm{a}$ \\
\hline $7-$ & $17 \mathrm{mM}\left(\mathrm{K}_{2} \mathrm{SiO}_{3}\right)$ & $4.424 \mathrm{a}-\mathrm{c}$ & $4.194 \mathrm{a}$ & $0.354 \mathrm{~b}-\mathrm{g}$ & $0.418 \mathrm{a}$ & $4.778 \mathrm{a}$ & $4.609 \mathrm{a}$ \\
\hline $8-$ & $34 \mathrm{mM}\left(\mathrm{K}_{2} \mathrm{SiO}_{3}\right)$ & $5.384 \mathrm{a}$ & $4.158 \mathrm{a}$ & $0.447 \mathrm{a}-\mathrm{c}$ & $0.376 \mathrm{a}$ & $5.831 \mathrm{a}-\mathrm{c}$ & $4.532 \mathrm{a}$ \\
\hline 9- & $1 \mathrm{mM}(\mathrm{SA})+4.25 \mathrm{mM}\left(\mathrm{K}_{2} \mathrm{SiO}_{3}\right)$ & $4.315 \mathrm{a}-\mathrm{c}$ & $3.408 \mathrm{a}$ & $0.408 \mathrm{a}-\mathrm{e}$ & $0.481 \mathrm{a}$ & $4.790 \mathrm{c}-\mathrm{e}$ & $3.889 \mathrm{a}$ \\
\hline $10-$ & $1 \mathrm{mM}(\mathrm{SA})+8.5 \mathrm{mM}\left(\mathrm{K}_{2} \mathrm{SiO}_{3}\right)$ & $2.775 \mathrm{c}-\mathrm{e}$ & $3.159 \mathrm{ab}$ & $0.295 \mathrm{c}-\mathrm{g}$ & $0.393 \mathrm{a}$ & $3.070 \mathrm{a}-\mathrm{c}$ & $3.552 \mathrm{ab}$ \\
\hline $11-$ & $1 \mathrm{mM}(\mathrm{SA})+17 \mathrm{mM}\left(\mathrm{K}_{2} \mathrm{SiO}_{3}\right)$ & $3.296 \mathrm{~b}-\mathrm{d}$ & $3.411 \mathrm{a}$ & $0.260 \mathrm{e}-\mathrm{g}$ & $0.419 \mathrm{a}$ & $4.223 \mathrm{~b}-\mathrm{e}$ & $3.830 \mathrm{a}$ \\
\hline $12-$ & $1 \mathrm{mM}(\mathrm{SA})+34 \mathrm{mM}\left(\mathrm{K}_{2} \mathrm{SiO}_{3}\right)$ & $2.862 \mathrm{c}-\mathrm{e}$ & $3.331 \mathrm{ab}$ & $0.281 \mathrm{~d}-\mathrm{g}$ & $0.412 \mathrm{a}$ & $3.143 \mathrm{a}-\mathrm{c}$ & $3.743 \mathrm{a}$ \\
\hline 13- & $2 \mathrm{mM}(\mathrm{SA})+4.25 \mathrm{mM}\left(\mathrm{K}_{2} \mathrm{SiO}_{3}\right)$ & $3.895 \mathrm{a}-\mathrm{c}$ & $3.751 \mathrm{a}$ & $0.457 \mathrm{ab}$ & $0.431 \mathrm{a}$ & $4.327 \mathrm{c}-\mathrm{e}$ & $4.182 \mathrm{a}$ \\
\hline 14- & $2 \mathrm{mM}(\mathrm{SA})+8.5 \mathrm{mM}\left(\mathrm{K}_{2} \mathrm{SiO}_{3}\right)$ & $2.863 \mathrm{c}-\mathrm{e}$ & $3.226 \mathrm{ab}$ & $0.243 \mathrm{fg}$ & $0.434 \mathrm{a}$ & $3.131 \mathrm{ab}$ & $3.660 \mathrm{ab}$ \\
\hline $15-$ & $2 \mathrm{mM}(\mathrm{SA})+17 \mathrm{mM}\left(\mathrm{K}_{2} \mathrm{SiO}_{3}\right)$ & $4.793 \mathrm{ab}$ & $4.111 \mathrm{a}$ & $0.388 \mathrm{a}-\mathrm{f}$ & $0.455 \mathrm{a}$ & $5.181 \mathrm{a}-\mathrm{d}$ & $4.567 \mathrm{a}$ \\
\hline $16-$ & $2 \mathrm{mM}(\mathrm{SA})+34 \mathrm{mM}\left(\mathrm{K}_{2} \mathrm{SiO}_{3}\right)$ & $3.682 \mathrm{a}-\mathrm{d}$ & $3.796 \mathrm{a}$ & $0.336 \mathrm{~b}-\mathrm{g}$ & $0.474 \mathrm{a}$ & $4.015 \mathrm{a}-\mathrm{c}$ & $4.270 \mathrm{a}$ \\
\hline $17-$ & $3 \mathrm{mM}(\mathrm{SA})+4.24 \mathrm{mM}\left(\mathrm{K}_{2} \mathrm{SiO}_{3}\right)$ & $4.074 \mathrm{a}-\mathrm{c}$ & $3.552 \mathrm{a}$ & $0.350 \mathrm{~b}-\mathrm{g}$ & $0.388 \mathrm{a}$ & $4.424 \mathrm{a}-\mathrm{c}$ & $3.941 \mathrm{a}$ \\
\hline $18-$ & $3 \mathrm{mM}(\mathrm{SA})+8.5 \mathrm{mM}\left(\mathrm{K}_{2} \mathrm{SiO}_{3}\right)$ & $4.267 \mathrm{a}-\mathrm{c}$ & $4.555 \mathrm{a}$ & $0.395 \mathrm{a}-\mathrm{f}$ & $0.396 \mathrm{a}$ & $4.662 \mathrm{a}-\mathrm{d}$ & $4.947 \mathrm{a}$ \\
\hline $19-$ & $3 \mathrm{mM}(\mathrm{SA})+17 \mathrm{mM}\left(\mathrm{K}_{2} \mathrm{SiO}_{3}\right)$ & $3.540 \mathrm{a}-\mathrm{d}$ & $3.707 \mathrm{a}$ & $0.286 \mathrm{~d}-\mathrm{g}$ & $0.326 \mathrm{a}$ & $3.826 \mathrm{a}-\mathrm{d}$ & $4.033 \mathrm{a}$ \\
\hline $20-$ & $3 \mathrm{mM}(\mathrm{SA})+34 \mathrm{mM}\left(\mathrm{K}_{2} \mathrm{SiO}_{3}\right)$ & $4.620 \mathrm{a}-\mathrm{c}$ & $3.863 \mathrm{a}$ & $0.427 \mathrm{a}-\mathrm{d}$ & $0.505 \mathrm{a}$ & $5.290 \mathrm{a}$ & $4.368 \mathrm{a}$ \\
\hline
\end{tabular}

SA, salicylic acid; $\mathrm{K}_{2} \mathrm{SiO}_{3}$, potassium silicates. Values having the same alphabetical letter (s) in common, within each column, do not significantly differ, using the revised L.S.D. test at 0.05 level of probability.

The postulated results are in arrangement, more or less, with those reported by Abd ElMageed $\boldsymbol{e t}$ al. (2016) who reported that the SA enhanced development squash plants with the highest values of soluble sugars. Also, Omar (2017) illustrated that foliar application of either SA at $200 \mathrm{ppm}$ or $\mathrm{Si}$ at $100 \mathrm{ppm}$ caused; significant increase in total sugars percentage of cucumber fruits compared to control plants.

\section{Plant chemical analysis}

\subsection{Leaf chlorophyll readings (SPAD)}

Data presented in Table (10) divulged that highest readings values of chlorophyll index were found when plants treated with $1 \mathrm{mM} \mathrm{SA}$ combined with 34 $\mathrm{mM}$ potassium silicate as 45.17 and 44.20 units, consecutively during both seasons, in addition to combination of $3 \mathrm{mM}$ SA plus $34 \mathrm{mM}$ of potassium silicate as 44.20 units during second season. This finding could be taken place due to the major role of SA and potassium silicate on photosynthetic activity and ultra-structure of leaf organelles (Shu and Liu, 2001) and photosynthetic rate (Wang et al., 2006). Further, this event may be occurred owing to ability SA and/ or potassium silicate to regulate the leaf photosynthetic functions as in case of cucumber readings (Wei et al., 2009), or because of the functions of material sprayed in increase photosynthetic pigments in cucumber leaves as reported by Mady (2009). These results are in harmony with those reported

Fayoum J. Agric. Res. \& Dev., Vol. 33, No.1, January, 2019 
EFFECT OF FOLIAR APPLICATION WITH SALICYLIC ACID

by Elwan and EL-Shatoury (2014); Abd El-Mageed et al. (2016) and AL-Rubaye and Atia (2016). As for Si application, the obtained results are similar, more or less, to those reported by Omar (2017) who illustrated that foliar application of Si at $100 \mathrm{ppm}$ caused significant increase in cucumber leaves chlorophyll a, b and $\mathrm{a}+\mathrm{b}$ compared to control plants. Also, Al-Aghabary et al. (2005) who found that foliar application of $\mathrm{Si}$ increased both $\mathrm{Chl} \mathrm{a}$ and $\mathrm{Chl} \mathrm{b}$ contents of tomato plants after 10 days of treatment. After 27 days of treatment, the difference of both $\mathrm{Chl} \mathrm{a}$ and $\mathrm{Chl} \mathrm{b}$ content between treatments was not significant. Also, Hellal et al. (2012) and Kardoni et al. (2013) reported that silicon application increased chlorophyll contents in shoot of faba bean.

\subsection{Chemical analysis of leaves and fruits characters}

\subsubsection{Leaves N, P, K and Si contents:}

Data outlined in Table (11) manifested that the lowest percentage values of leaves $\mathrm{N}, \mathrm{P}, \mathrm{K}$ and determined of Si element were obtained from untreated plants during both seasons. The highest percentages of leaves $\mathrm{N}$ concentrations were obtained when plants treated with $8.5 \mathrm{mM}$ potassium silicate as 2.398 and $2.075 \%$ during both seasons, progressively. With regard to leaves $\mathrm{P}$ content, during the first season, nonsignificant effects were found among all treatments, while during the second one plants treated with $2 \mathrm{mM}$ salicylic acid alone or in

Table (10): Percentages of squash leaves nutrient contents as affected by foliar application with salicylic acid, potassium silicate and their combinations during the summer seasons of 2016 and 2017.

\begin{tabular}{|c|c|c|c|c|c|c|c|c|c|c|c|}
\hline & \multirow{3}{*}{ Treatments } & \multirow{2}{*}{\multicolumn{2}{|c|}{$\begin{array}{l}\text { Chlorophyll index } \\
\text { (reading by SPAD) }\end{array}$}} & \multicolumn{8}{|c|}{ Nutrient contents of leaves (\% DW) } \\
\hline & & & & \multicolumn{2}{|c|}{$\mathbf{N}$} & \multicolumn{2}{|c|}{$\mathbf{P}$} & \multicolumn{2}{|c|}{$\mathbf{K}$} & \multicolumn{2}{|c|}{$\mathbf{S i}$} \\
\hline & & 2016 & 2017 & 2016 & 2017 & 2016 & 2017 & 2016 & 2017 & 2016 & 2017 \\
\hline $1-$ & Control & $35.63 \mathrm{e}$ & $30.77 \mathrm{~d}$ & $1.238 \mathrm{c}$ & $1.158 \mathrm{~g}$ & $0.342 \mathrm{a}$ & $0.410 \mathrm{~d}$ & $1.55 \mathrm{~g}$ & $1.50 \mathrm{j}$ & $1.62 \mathrm{r}$ & $1.78 \mathrm{r}$ \\
\hline $2-$ & $1 \mathrm{mM}(\mathrm{SA})$ & 39.20 a-e & $39.40 \mathrm{a}-\mathrm{c}$ & $1.339 \mathrm{bc}$ & $1.507 \mathrm{ef}$ & $0.462 \mathrm{a}$ & $0.527 \mathrm{a}-\mathrm{d}$ & $1.97 \mathrm{e}-\mathrm{g}$ & $1.76 \mathrm{ij}$ & $1.67 \mathrm{qr}$ & $1.83 \mathrm{r}$ \\
\hline 3- & $2 \mathrm{mM}(\mathrm{SA})$ & $38.63 \mathrm{~b}-\mathrm{e}$ & $38.33 \mathrm{bc}$ & $2.018 \mathrm{a}-\mathrm{c}$ & $1.872 \mathrm{a}-\mathrm{d}$ & $0.407 \mathrm{a}$ & $0.600 \mathrm{a}$ & $2.27 \mathrm{c}-\mathrm{f}$ & $1.82 \mathrm{~h}-\mathrm{j}$ & $1.72 \mathrm{q}$ & $1.90 \mathrm{q}$ \\
\hline $4-$ & $3 \mathrm{mM}(\mathrm{SA})$ & $42.10 \mathrm{a}-\mathrm{c}$ & $38.70 \mathrm{bc}$ & $1.561 \mathrm{a}-\mathrm{c}$ & $1.722 \mathrm{~b}-\mathrm{e}$ & $0.426 \mathrm{a}$ & $0.533 \mathrm{a}-\mathrm{d}$ & $2.27 \mathrm{c}-\mathrm{f}$ & $1.95 \mathrm{~g}-\mathrm{i}$ & $1.78 \mathrm{p}$ & $1.94 \mathrm{q}$ \\
\hline $5-$ & $4.25 \mathrm{mM}\left(\mathrm{K}_{2} \mathrm{SiO}_{3}\right)$ & $42.03 \mathrm{a}-\mathrm{c}$ & $42.33 \mathrm{a}-\mathrm{c}$ & $1.700 \mathrm{a}-\mathrm{c}$ & $2.034 \mathrm{a}-\mathrm{c}$ & $0.436 \mathrm{a}$ & $0.500 \mathrm{a}-\mathrm{c}$ & $2.05 \mathrm{e}-\mathrm{g}$ & $2.16 \mathrm{fgh}$ & $1.86 \mathrm{o}$ & $2.02 \mathrm{p}$ \\
\hline 6- & $8.5 \mathrm{mM}\left(\mathrm{K}_{2} \mathrm{SiO}_{3}\right)$ & 39.47 a-e & $39.20 \mathrm{a}-\mathrm{c}$ & $2.398 \mathrm{a}$ & $2.075 \mathrm{a}$ & $0.367 \mathrm{a}$ & $0.473 \mathrm{a}-\mathrm{d}$ & $2.20 \mathrm{~d}-\mathrm{f}$ & $2.45 \mathrm{c}-\mathrm{f}$ & $1.98 \mathrm{n}$ & $2.11 \mathrm{o}$ \\
\hline $7-$ & $17 \mathrm{mM}\left(\mathrm{K}_{2} \mathrm{SiO}_{3}\right)$ & 40.50 a-e & $40.53 \mathrm{a}-\mathrm{c}$ & $2.098 \mathrm{ab}$ & $1.846 \mathrm{a}-\mathrm{e}$ & $0.400 \mathrm{a}$ & $0.480 \mathrm{a}-\mathrm{d}$ & $2.37 \mathrm{~b}-\mathrm{f}$ & $2.52 \mathrm{c}-\mathrm{f}$ & $2.33 \mathrm{k}$ & $2.44 \mathrm{k}$ \\
\hline $8-$ & $34 \mathrm{mM}\left(\mathrm{K}_{2} \mathrm{SiO}_{3}\right)$ & 40.87 a-e & $40.87 \mathrm{a}-\mathrm{c}$ & $2.075 \mathrm{a}-\mathrm{c}$ & $1.961 \mathrm{a}-\mathrm{d}$ & $0.406 \mathrm{a}$ & $0.510 \mathrm{~b}-\mathrm{d}$ & $2.45 \mathrm{~b}-\mathrm{e}$ & $2.67 \mathrm{~b}-\mathrm{d}$ & $2.67 \mathrm{~g}$ & $2.78 \mathrm{~g}$ \\
\hline 9- & $1 \mathrm{mM}(\mathrm{SA})+4.25 \mathrm{mM}\left(\mathrm{K}_{2} \mathrm{SiO}_{3}\right)$ & 40.60 a-e & $37.77 \mathrm{c}$ & $2.121 \mathrm{ab}$ & $2.066 \mathrm{ab}$ & $0.409 \mathrm{a}$ & $0.490 \mathrm{ab}$ & $2.30 \mathrm{c}-\mathrm{f}$ & $2.19 \mathrm{fg}$ & $2.09 \mathrm{~m}$ & $2.22 n$ \\
\hline $10-$ & $1 \mathrm{mM}(\mathrm{SA})+8.5 \mathrm{mM}\left(\mathrm{K}_{2} \mathrm{SiO}_{3}\right)$ & $35.93 \mathrm{de}$ & $37.67 \mathrm{c}$ & $2.174 \mathrm{ab}$ & $1.928 \mathrm{a}-\mathrm{d}$ & $0.420 \mathrm{a}$ & $0.533 \mathrm{a}-\mathrm{d}$ & $2.43 \mathrm{~b}-\mathrm{e}$ & $2.25 \mathrm{e}-\mathrm{g}$ & $2.43 \mathrm{cj}$ & $2.39 \mathrm{j}$ \\
\hline $11-$ & $7 \mathrm{mM} \mathrm{(1}$ & $37.23 \mathrm{c}-\mathrm{e}$ & $39.37 \mathrm{a}-\mathrm{c}$ & $1.519 \mathrm{bc}$ & $1.273 \mathrm{fg}$ & $0.435 \mathrm{a}$ & $0.597 \mathrm{a}-\mathrm{d}$ & $2.23 \mathrm{~d}-\mathrm{f}$ & $2.39 \mathrm{~d}-\mathrm{f}$ & $2.74 \mathrm{f}$ & $2.20 \mathrm{f}$ \\
\hline $12-$ & $\left.{ }_{2} \mathrm{SiO}_{3}\right)$ & $45.17 \mathrm{a}$ & $0 \mathrm{a}$ & $1.489 \mathrm{bc}$ & $1.801 \mathrm{a}-\mathrm{e}$ & $0.385 \mathrm{a}$ & $0.557 \mathrm{a}-\mathrm{d}$ & $3.30 \mathrm{a}$ & $3.04 \mathrm{a}$ & $3.01 \mathrm{c}$ & $3.02 \mathrm{c}$ \\
\hline $13-$ & $2 \mathrm{mM}(\mathrm{SA})+4.25 \mathrm{mM}\left(\mathrm{K}_{2} \mathrm{SiO}_{3}\right)$ & 41.87 a-e & $40.20 \mathrm{a}-\mathrm{c}$ & $1.384 \mathrm{bc}$ & $1.762 \mathrm{a}-\mathrm{e}$ & $0.480 \mathrm{a}$ & $0.537 \mathrm{a}-\mathrm{d}$ & $2.73 \mathrm{a}-\mathrm{d}$ & $2.62 \mathrm{~b}-\mathrm{e}$ & $2.14 \mathrm{~m}$ & $2.73 \mathrm{~m}$ \\
\hline 14- & $2 \mathrm{mM}(\mathrm{SA})+8.5 \mathrm{mM}\left(\mathrm{K}_{2} \mathrm{SiO}_{3}\right)$ & 39.73 a-e & $38.20 \mathrm{c}$ & $1.542 \mathrm{bc}$ & $1.672 \mathrm{de}$ & $0.498 \mathrm{a}$ & $0.510 \mathrm{a}-\mathrm{d}$ & $2.55 \mathrm{~b}-\mathrm{e}$ & $2.58 \mathrm{~b}-\mathrm{e}$ & $2.52 \mathrm{i}$ & $2.46 \mathrm{i}$ \\
\hline $15-$ & $2 \mathrm{mM}(\mathrm{SA})+17 \mathrm{mM}\left(\mathrm{K}_{2} \mathrm{SiO}_{3}\right)$ & $36.17 \mathrm{c}-\mathrm{e}$ & $37.17 \mathrm{c}$ & $1.967 \mathrm{a}-\mathrm{c}$ & $2.010 \mathrm{a}-\mathrm{d}$ & $0.413 \mathrm{a}$ & $0.543 \mathrm{a}$ & $2.83 \mathrm{a}-\mathrm{c}$ & $2.80 \mathrm{a}-\mathrm{c}$ & $2.85 \mathrm{e}$ & $2.83 \mathrm{e}$ \\
\hline $16-$ & $2 \mathrm{mM}(\mathrm{SA})+34 \mathrm{mM}\left(\mathrm{K}_{2} \mathrm{SiO}_{3}\right)$ & 40.87 a-e & $40.67 \mathrm{a}-\mathrm{c}$ & $2.052 \mathrm{a}-\mathrm{c}$ & $1.963 \mathrm{a}-\mathrm{d}$ & $0.445 \mathrm{a}$ & $0.567 \mathrm{bc}$ & $2.90 \mathrm{ab}$ & $3.09 \mathrm{a}$ & $3.11 \mathrm{~b}$ & $3.11 \mathrm{~b}$ \\
\hline $17-$ & $3 \mathrm{mM}(\mathrm{SA})+4.24 \mathrm{mM}\left(\mathrm{K}_{2} \mathrm{SiO}_{3}\right)$ & $38.10 \mathrm{c}-\mathrm{e}$ & $37.83 \mathrm{c}$ & $1.794 \mathrm{a}-\mathrm{c}$ & $1.928 \mathrm{a}-\mathrm{d}$ & $0.472 \mathrm{a}$ & $0.477 \mathrm{~cd}$ & $2.30 \mathrm{c}-\mathrm{f}$ & $2.47 \mathrm{c}-\mathrm{f}$ & 2.251 & 2.621 \\
\hline $18-$ & $3 \mathrm{mM}(\mathrm{SA})+8.5 \mathrm{mM}\left(\mathrm{K}_{2} \mathrm{SiO}_{3}\right)$ & $44.53 \mathrm{ab}$ & $43.73 \mathrm{ab}$ & $1.862 \mathrm{a}-\mathrm{c}$ & $1.951 \mathrm{a}-\mathrm{d}$ & $0.426 \mathrm{a}$ & $0.527 \mathrm{ab}$ & $1.83 \mathrm{fg}$ & $2.93 \mathrm{ab}$ & $2.59 \mathrm{~h}$ & $2.63 \mathrm{~h}$ \\
\hline $19-$ & $+17 \mathrm{mM}\left(\mathrm{K}_{2} \mathrm{SiO}_{3}\right)$ & & & $1.858 \mathrm{a}-\mathrm{c}$ & $1.915 \mathrm{a}-\mathrm{d}$ & $0.447 \mathrm{a}$ & $0.573 \mathrm{a}-\mathrm{d}$ & $2.73 \mathrm{a}-\mathrm{d}$ & $2.75 \mathrm{a}-\mathrm{d}$ & $2.92 \mathrm{~d}$ & $3.04 \mathrm{~d}$ \\
\hline $20-$ & $3 \mathrm{mM}(\mathrm{SA})+34 \mathrm{mM}\left(\mathrm{K}_{2} \mathrm{SiO}_{3}\right)$ & $40.03 \mathrm{a}-\mathrm{d}$ & $44.20 \mathrm{a}$ & $2.087 \mathrm{a}-\mathrm{c}$ & $1.713 \mathrm{c}-\mathrm{e}$ & $0.388 \mathrm{a}$ & $0.570 \mathrm{ab}$ & $2.90 \mathrm{ab}$ & $3.08 \mathrm{a}$ & $3.19 \mathrm{a}$ & $3.29 \mathrm{a}$ \\
\hline
\end{tabular}

- SA, salicylic acid; $\mathrm{K}_{2} \mathrm{SiO}_{3}$, potassium silicate. -Values having the same alphabetical letter (s) in common, within each column, do not significantly differ, using the revised L.S.D. test at 0.05 level of probability.

Fayoum J. Agric. Res. \& Dev., Vol. 33, No.1, January, 2019 
Abd-Elaziz. S. A ${ }^{1}$, et al.,

combination with $17 \mathrm{mM}$ potassium silicate reflected the highest percent values as 0.600 and $0.543 \%$, respectively. The highest percent values of leaves $\mathrm{K}$ content were obtained from plants treated with $1 \mathrm{mM}$ salicylic acid in combination with $34 \mathrm{mM}$ potassium silicate during both seasons as 3.30 and $3.04 \%$, in succession, in addition to the combination of $3 \mathrm{mM} \mathrm{SA}$ and same level of potassium silicate as 2.90 and $3.08 \%$ during the second season. With regard to leaves Si content, plants that treated with 3 $\mathrm{mM}$ SA plus $34 \mathrm{mM}$ potassium silicate showed highest concentration during both seasons as 3.19 and $3.29 \%$, respectively. In this concern, Grown (2012) reported such stimulatory effect of SA on concentration of nutrition elements and yield components and attributed these findings to the effect of salicylic acid on many biochemical and physiological processes that were reflected on improving vegetative growth and active translocation of photosynthesis products from source to sink. These results agree, more or less, with those reported by Elwan and EL-Shatoury (2014) on squash, Pramod Kumar et al., 2010 and Omar (2017) on cucumber.

As for Si treatments, the gained results are in parallel with those found by Omar (2017) who illustrated that foliar application of $\mathrm{Si}$ at $100 \mathrm{ppm}$; caused significant increase in cucumber $\mathrm{N}, \mathrm{P}$ and $\mathrm{K}$ leaves percentage compared to control plants. Jafari et al. (2015) reported that under osmotic stress, Si +SA treatment, significantly, increased non-enzymatic antioxidants, total phenolic compounds, anthocyanins, flavonoids, and $\mathrm{Si}, \mathrm{K}^{+}, \mathrm{Ca}^{+2}$ content in cucumber shoots.

\subsubsection{Fruits N, P, K and Si contents}

Data postulated in Table (11) illustrated that control (untreated plants) showed the lowest values for nutrient contents of fruits (i.e. N, P, K and Si fruits content) as 1.10 and $1.095 \%$ for $\mathrm{N}, 0.352$ and $0.458 \%$ for $\mathrm{P}, 3.94$ and $4.17 \%$ for $\mathrm{K}$, and 0.52 and 0.66 $\%$ for Si during both years, respectively. The highest percentage values of both $\mathrm{N}$ and P fruits' content were 1.68 and $1.849 \%$ for the former and 0.716 and $0.641 \%$ for the later, respectively, were recorded from plants treated with $2 \mathrm{mM}$ SA during both seasons. Whereas, the combination of $3 \mathrm{mM}$ SA plus $8.5 \mathrm{mM}$ potassium silicate; brought about the highest percentage values of fruits $\mathrm{K}$ content during both seasons as 7.75 and $7.22 \%$, each in turn. Regarding fruits Si content, plants sprayed with $3 \mathrm{mM}$ SA plus $34 \mathrm{mM}$ potassium silicate; recorded the highest fruits Si concentration during both seasons of the study as 1.54 and $1.72 \%$, consecutively. The gained results could be attributed to foliar application of SA and Si caused increased in nutrient content of leaves as illustrated in Table (9) then transferred to squash fruits. The obtained results are similar, more or less, with those illustrated by AL-Rubaye and Atia (2016) who determined that the highest $\mathrm{N}, \mathrm{P}, \mathrm{K}$ and $\mathrm{Zn}$ contents in squash fruits were found to be achieved due to applying $5 \mathrm{mM}$ concentration of SA compared to the other concentration. 
EFFECT OF FOLIAR APPLICATION WITH SALICYLIC ACID

Table (11): Percentages of squash fruits nutrient contents as affected by foliar application with salicylic acid, potassium silicate and their combinations during the summer seasons of 2016 and 2017.

\begin{tabular}{|c|c|c|c|c|c|c|c|c|c|}
\hline & \multirow{3}{*}{ Treatments } & \multicolumn{8}{|c|}{ Nutrient contents of fruits (\% DW) } \\
\hline & & \multicolumn{2}{|c|}{$\mathbf{N}$} & \multicolumn{2}{|c|}{$\mathbf{P}$} & \multicolumn{2}{|c|}{$\mathbf{K}$} & \multicolumn{2}{|c|}{$\mathbf{S i}$} \\
\hline & & 2016 & 2017 & 2016 & 2017 & 2016 & 2017 & 2016 & 2017 \\
\hline $1-$ & Control & $1.10 \mathrm{c}$ & $1.095 \mathrm{~g}$ & $0.352 \mathrm{gh}$ & $0.458 \mathrm{c}$ & $3.94 \mathrm{hi}$ & $4.17 \mathrm{j}$ & $0.52 \mathrm{p}$ & $0.66 \mathrm{n}$ \\
\hline $2-$ & $1 \mathrm{mM}(\mathrm{SA})$ & $1.67 \mathrm{ab}$ & $1.411 \mathrm{~b}-\mathrm{g}$ & $0.588 \mathrm{a}-\mathrm{d}$ & $0.612 \mathrm{ab}$ & $6.13 \mathrm{~b}-\mathrm{g}$ & $4.69 \mathrm{ij}$ & $0.55 \mathrm{op}$ & $0.71 \mathrm{~m}$ \\
\hline $3-$ & $2 \mathrm{mM}(\mathrm{SA})$ & $1.68 \mathrm{a}$ & $1.849 \mathrm{a}$ & $0.716 \mathrm{a}$ & $0.641 \mathrm{a}$ & $5.52 \mathrm{e}-\mathrm{h}$ & $5.00 \mathrm{~g}-\mathrm{j}$ & 0.60 no & $0.73 \mathrm{~m}$ \\
\hline $4-$ & $3 \mathrm{mM}(\mathrm{SA})$ & $1.14 \mathrm{bc}$ & $1.195 \mathrm{fg}$ & $0.449 \mathrm{~d}-\mathrm{h}$ & $0.565 \mathrm{a}-\mathrm{c}$ & $5.00 \mathrm{f}-\mathrm{i}$ & $4.86 \mathrm{~h}-\mathrm{j}$ & $0.62 \mathrm{mn}$ & 0.811 \\
\hline $5-$ & $4.25 \mathrm{mM}\left(\mathrm{K}_{2} \mathrm{SiO}_{3}\right)$ & $1.29 \mathrm{a}-\mathrm{c}$ & $1.287 \mathrm{~d}-\mathrm{g}$ & $0.454 \mathrm{~d}-\mathrm{h}$ & $0.538 \mathrm{a}-\mathrm{c}$ & 7.00 a-e & $5.92 \mathrm{e}-\mathrm{g}$ & $0.67 \mathrm{~lm}$ & 0.851 \\
\hline $6-$ & $8.5 \mathrm{mM}\left(\mathrm{K}_{2} \mathrm{SiO}_{3}\right)$ & $1.53 \mathrm{a}-\mathrm{c}$ & $1.419 \mathrm{~b}-\mathrm{g}$ & $0.614 \mathrm{a}-\mathrm{c}$ & $0.614 \mathrm{ab}$ & $5.37 \mathrm{f}-\mathrm{h}$ & $6.32 \mathrm{c}-\mathrm{f}$ & 0.711 & $0.93 \mathrm{k}$ \\
\hline $7-$ & $17 \mathrm{mM}\left(\mathrm{K}_{2} \mathrm{SiO}_{3}\right)$ & $1.50 \mathrm{a}-\mathrm{c}$ & $1.693 \mathrm{a}-\mathrm{c}$ & $0.423 \mathrm{e}-\mathrm{h}$ & $0.567 \mathrm{ab}$ & $5.12 \mathrm{f}-\mathrm{i}$ & $6.29 \mathrm{~d}-\mathrm{f}$ & $0.95 \mathrm{i}$ & $1.17 \mathrm{~h}$ \\
\hline $8-$ & $34 \mathrm{mM}\left(\mathrm{K}_{2} \mathrm{SiO}_{3}\right)$ & $1.44 \mathrm{a}-\mathrm{c}$ & $1.595 \mathrm{a}-\mathrm{e}$ & $0.460 \mathrm{c}-\mathrm{h}$ & $0.600 \mathrm{ab}$ & $6.50 \mathrm{a}-\mathrm{f}$ & $6.83 \mathrm{a}-\mathrm{e}$ & $1.17 \mathrm{f}$ & $1.42 \mathrm{e}$ \\
\hline $9-$ & $1 \mathrm{mM}(\mathrm{SA})+4.25 \mathrm{mM}\left(\mathrm{K}_{2} \mathrm{SiO}_{3}\right)$ & $1.44 \mathrm{a}-\mathrm{c}$ & $1.349 \mathrm{~b}-\mathrm{g}$ & $0.507 \mathrm{~b}-\mathrm{g}$ & $0.568 \mathrm{ab}$ & $3.75 \mathrm{i}$ & $5.65 \mathrm{f}-\mathrm{h}$ & $0.78 \mathrm{k}$ & $1.01 \mathrm{j}$ \\
\hline $10-$ & $1 \mathrm{mM}(\mathrm{SA})+8.5 \mathrm{mM}\left(\mathrm{K}_{2} \mathrm{SiO}_{3}\right)$ & $1.30 \mathrm{a}-\mathrm{c}$ & $1.217 \mathrm{~d}-\mathrm{g}$ & $0.554 \mathrm{~b}-\mathrm{f}$ & $0.607 \mathrm{ab}$ & $7.19 \mathrm{a}-\mathrm{d}$ & $6.83 \mathrm{a}-\mathrm{c}$ & $1.02 \mathrm{~h}$ & $1.34 \mathrm{~g}$ \\
\hline $11-$ & $1 \mathrm{mM}(\mathrm{SA})+17 \mathrm{mM}\left(\mathrm{K}_{2} \mathrm{SiO}_{3}\right)$ & $1.34 \mathrm{a}-\mathrm{c}$ & $1.345 \mathrm{~b}-\mathrm{g}$ & $0.515 \mathrm{~b}-\mathrm{f}$ & $0.559 \mathrm{a}-\mathrm{c}$ & $5.81 \mathrm{~d}-\mathrm{g}$ & $6.76 \mathrm{c}-\mathrm{f}$ & $1.23 \mathrm{e}$ & $1.41 \mathrm{~d}$ \\
\hline $12-$ & $1 \mathrm{mM}(\mathrm{SA})+34 \mathrm{mM}\left(\mathrm{K}_{2} \mathrm{SiO}_{3}\right)$ & $1.48 \mathrm{a}-\mathrm{c}$ & $1.413 \mathrm{~b}-\mathrm{g}$ & $0.399 \mathrm{f}-\mathrm{h}$ & $0.531 \mathrm{bc}$ & $6.44 \mathrm{a}-\mathrm{f}$ & 6.58 a-e & $1.42 \mathrm{c}$ & $1.59 \mathrm{a}$ \\
\hline $13-$ & $2 \mathrm{mM}(\mathrm{SA})+4.25 \mathrm{mM}\left(\mathrm{K}_{2} \mathrm{SiO}_{3}\right)$ & $1.45 \mathrm{a}-\mathrm{c}$ & $1.638 \mathrm{a}-\mathrm{d}$ & $0.345 \mathrm{~h}$ & $0.532 \mathrm{bc}$ & $4.56 \mathrm{~g}-\mathrm{i}$ & $6.15 \mathrm{f}-\mathrm{i}$ & $0.84 \mathrm{j}$ & $1.38 \mathrm{j}$ \\
\hline 14- & $2 \mathrm{mM}(\mathrm{SA})+8.5 \mathrm{mM}\left(\mathrm{K}_{2} \mathrm{SiO}_{3}\right)$ & $1.64 \mathrm{ab}$ & $1.388 \mathrm{~b}-\mathrm{g}$ & $0.540 \mathrm{~b}-\mathrm{f}$ & $0.595 \mathrm{ab}$ & $5.54 \mathrm{e}-\mathrm{h}$ & $5.71 \mathrm{ef}$ & $1.07 \mathrm{~g}$ & $1.22 \mathrm{f}$ \\
\hline $15-$ & $2 \mathrm{mM}(\mathrm{SA})+17 \mathrm{mM}\left(\mathrm{K}_{2} \mathrm{SiO}_{3}\right)$ & $1.39 \mathrm{a}-\mathrm{c}$ & $1.628 \mathrm{a}-\mathrm{d}$ & $0.541 \mathrm{~b}-\mathrm{f}$ & $0.581 \mathrm{ab}$ & $7.63 \mathrm{ab}$ & $6.71 \mathrm{ab}$ & $1.27 \mathrm{e}$ & $1.45 \mathrm{c}$ \\
\hline $16-$ & $2 \mathrm{mM}(\mathrm{SA})+34 \mathrm{mM}\left(\mathrm{K}_{2} \mathrm{SiO}_{3}\right)$ & $1.59 \mathrm{a}-\mathrm{c}$ & $1.597 \mathrm{a}-\mathrm{e}$ & $0.636 \mathrm{ab}$ & $0.605 \mathrm{ab}$ & $5.94 \mathrm{c}-\mathrm{g}$ & $6.98 \mathrm{c}-\mathrm{f}$ & $1.48 \mathrm{~b}$ & $1.64 \mathrm{a}$ \\
\hline $17-$ & $3 \mathrm{mM}(\mathrm{SA})+4.24 \mathrm{mM}\left(\mathrm{K}_{2} \mathrm{SiO}_{3}\right)$ & $1.30 \mathrm{a}-\mathrm{c}$ & $1.322 \mathrm{c}-\mathrm{g}$ & $0.591 \mathrm{a}-\mathrm{d}$ & $0.564 \mathrm{a}-\mathrm{c}$ & $5.69 \mathrm{~d}-\mathrm{g}$ & $6.29 \mathrm{ef}$ & $0.89 \mathrm{j}$ & $1.31 \mathrm{i}$ \\
\hline $18-$ & $3 \mathrm{mM}(\mathrm{SA})+8.5 \mathrm{mM}\left(\mathrm{K}_{2} \mathrm{SiO}_{3}\right)$ & $1.21 \mathrm{a}-\mathrm{c}$ & $1.305 \mathrm{c}-\mathrm{g}$ & $0.557 \mathrm{a}-\mathrm{f}$ & $0.597 \mathrm{ab}$ & $7.75 \mathrm{a}$ & $7.22 \mathrm{a}$ & $1.11 \mathrm{~g}$ & $1.28 \mathrm{e}$ \\
\hline $19-$ & $3 \mathrm{mM}(\mathrm{SA})+17 \mathrm{mM}\left(\mathrm{K}_{2} \mathrm{SiO}_{3}\right)$ & $1.47 \mathrm{a}-\mathrm{c}$ & $1.527 \mathrm{a}-\mathrm{f}$ & $0.595 \mathrm{a}-\mathrm{d}$ & $0.570 \mathrm{ab}$ & $7.52 \mathrm{a}-\mathrm{c}$ & $7.17 \mathrm{a}-\mathrm{d}$ & $1.34 \mathrm{~d}$ & $1.59 \mathrm{~b}$ \\
\hline $20-$ & $3 \mathrm{mM}(\mathrm{SA})+34 \mathrm{mM}\left(\mathrm{K}_{2} \mathrm{SiO}_{3}\right)$ & $1.66 \mathrm{ab}$ & $1.723 \mathrm{ab}$ & $0.567 \mathrm{a}-\mathrm{e}$ & $0.643 \mathrm{a}$ & $6.19 \mathrm{a}-\mathrm{f}$ & $6.80 \mathrm{~b}-\mathrm{e}$ & $1.54 \mathrm{a}$ & $1.72 \mathrm{a}$ \\
\hline
\end{tabular}

- SA, salicylic acid; $\mathrm{K}_{2} \mathrm{SiO}_{3}$, potassium silicate.

- Values having the same alphabetical letter (s) in common, within each column, do not significantly differ, using the revised L.S.D. test at 0.05 level of probability.

Also, Omar (2017) illustrated that foliar application of SA at $200 \mathrm{ppm}$ led to significant increase in cucumber N, P and K fruits percentages compared to control plants.

Finally, it could be said that the utilization of the foliar application of SA at the rate of $2 \mathrm{mM}$ with $8.5 \mathrm{mM}$ potassium silicate can be recommended for producing good growth, high yield and quality of summer squash under the environmental conditions of Behiera Governorate and other similar regions.

\section{REFERENCES}

Abd El-All, H.M., S.M. Ali and S.M. Shahin (2013). Improvement growth, yield and quality of squash (Cucurbita pepo L.) plant under salinity conditions by magnetized water, amino acids and selenium. J. Applied Sci. Res., 9: 937944.

Abd El-Mageed, T. A., W.M. Semida, G. F. Mohamed and M.M. Rady (2016). Combined effect of foliar-applied salicylic acid and deficit irrigation on physiological-anatomical responses, and yield of squash plants under saline soil. South African J. Botany, 106: 8-16.

Al-Aghabary, K., Z. Zhu and Q. Shi (2005). Influence of Silicon Supply on Chlorophyll Content, Chlorophyll Fluorescence, and Anti oxidative Enzyme Activities in Tomato Plants under Salt Stress. J. Plant Nutri., 27 (12): 2101-2115.

AL-Rubaye, B. C. H. and E. A. Atia (2016). The influence of foliar sprays on the growth and yield of summer squash. International J. Scientific \& Engineering Research, 7 (6): 664-669.

Fayoum J. Agric. Res. \& Dev., Vol. 33, No.1, January, 2019 
Abd-Elaziz. S. A $A^{1}$, et al.,

A.O. A. C. (1992). Official methods of analysis, 12th Ed Association of Official Analytical Chemists. Washington, D.C.

APHA (1992). Standard method for the examination of water and wastes water. $18^{\text {th }}$ ed. American Public Health Association, Washington. D.C.

Balakhnina, T and A. Borkowska (2013) Effects of silicon on plant resistance to environmental stresses: review. Int. Agrophys, 27,225 -232.

Bhupinder, S. and K. Usha (2003). Salicylic acid induced physiological and biochemical changes in wheat seedlings under water stress. Plant Growth Regul., 39: 137-141.

Boyer, J. S. (1982). Plant productivity and environment. Science, 218: 443-448. Doi: 10.1126/science. 218. 4571.443. (PubMed) (Cross ref.).

Bricker, B. (1991). MSTATC: A Micro Computer Program from the Design Management and Analysis of Agronomic Research Experiments. Michigan State University, USA.

Buttaro, D., A. Bonasia, A. Minuto, F. Serio and P. Santamaria (2009). Effect of silicon in the nutrient solution on the incidence of the powdery mildew and quality traits in carosello and barattiere (Cucumis melo L.) grown in a soilless system. J. Hort. Sci. \& Biotechnology, 84: 300 - 304.

Canakci, S. and O. Munzuroglu (2007). Effect of Acetylsalicylic Acid on germination growth and chlorophyll amount of cucumber (Cucumis sativus L) seeds. Pakistan J. Biol. Sci., 10 (17): 2930-2934.

El-Rawy, K.M. and A.M. Khalf-Allah (1980). Design and Analysis of Agricultural Experiments. Mousel Univ., Iraq (In Arabic) 448 PP.

Elwan, M.W.M. and R.S.A. EL-Shatoury (2014). Alleviation of $\mathrm{NaCl}$ stress in summer squash 'Eskandrani' by foliar application of salicylic acid. J. Hort. Res., 22(2): 131-137.

Gomez, K.A. and A. A. Gomez. (1984). Statistical procedures for agriculture Research. Second Ed. Willey inter Science, Pp: 357-423.

Grown, B. (2012). Physiological role of salicylic acid in improving performance, yield and some biochemical aspects of sunflower plant grown under newly reclaimed sandy soil. Australian J. Basic \& App. Sci., 6 (4), 82-89.

Hellal, F., M. Abdelhameid, D. Abo-Rasha and R. Zewaiy (2012). Alleviation of the adverse effects of soil salinity stress by foliar application of silicon on faba bean (Vicia faba L.). J. Appl. Sci. Res., 8:4428-4433.

Jafari, S.R., S.M.J. Arvin and K. M. Kalantari (2015). Response of cucumber (Cucumis sativus L.) seedlings to exogenous silicon and salicylic acid under osmotic stress. Acta Biologica Szegediensis, 59(1):25-33.

Jamali, B., S. Eshghi and E. Tafazoli (2011). Vegetative and reproductive growth of Strawberry plants cv. "Pajaro" affected by salicylic acid and nickel. J. Agric. Sci. Tech., (13): 895-904.

Jayawardana, H.A.R.K., H.L.D. Weerahewa and M.D.J.S. Saparamadu (2014). Effect of root or foliar application of soluble silicon on plant growth, fruit quality and anthracnose development of Capsicum, Tropical Agric. Res., 26 (1): $74-81$.

Fayoum J. Agric. Res. \& Dev., Vol. 33, No.1, January, 2019 
EFFECT OF FOLIAR APPLICATION WITH SALICYLIC ACID

Kardoni, F., S. M.osavi, S. parande and M. Torbaghan (2013). Effect and silicon application on yield and component yield of faba bean (Vicia faba). Int. J. Agric Crop Sci., 6: 814- 818.

Kazemi, M. (2014) Effect of foliar Application with Salicylic and methyl jasmonate on growth, flowering yield and fruit quality of tomato. Bull. Env. Pharmacol. Life Sci., 3 (2): 154-158.

Li, H., Y. Zhu, Y. Hu, W. Han and H. Gong (2015). Beneficial effects of silicon in alleviating salinity stress of tomato seedlings grown under sand culture. Acta physiol. Plant, 37:1-9.

Liang, Y., M. Nikolic, R. Bélanger, H. Gong and A. Song (2015). Silicon in Agriculture, Springer Dordrecht Heidelberg New York London. Pp. 250.

Mady, M. A. (2009). Effect of foliar Application with salicylic acid vitamin E on growth and productivity of tomato (lycopersicon escylentym, Mill.) plant. J. Agric. Sci. Mansoura Univ., 34 (6): 6735- 6746.

Malik, C. P. and M. B. Singh (1980). Plant enzymology and histoenzymology. A Text. Manual. Kalyani Publishers, New Delhi.

Marquard, R. D. and J. L. Tipton (1987). Relationship between extractable chlorophyll and an in situ method to estimate leaf greenness. HortScience, 22 (6): 1327.

Matichenkov, V. and E. Bocharnikova (2008). New generation of silicon fertilizers. PP. 71. In Malcolm Keeping (ed.) silicon in Agriculture Conference sout Africa (2008), $4^{\text {th }}$ International conference Abstracts .University of Kwazulu -Natal, Wild cost sun, port Edward, Kwazulu-Natal, South Africa.

Murphy, J. and J.P.Riely (1962). A modified single solution method for determination of phosphate in natural waters. Anal. Chim. Acta. 29: 31-36.

Okalebo, J. R., K.W. Cuthua and P. J. Woomer (2002). Laboratory methods of soil and plant analysis- A working manual. TSBF- CIAT and SACRED Africa, Nairobi, Kenya. Pp. 128.

Omar, A.A.A.(2017). Improving the fruit yield and quality of the grafted cucumber plants grown under high polyethylene tunnels. M. Sc. Unpublished thesis, Fac. Agric. Mansoura Univ. Egypt, 69 p.

Pregl, E. (1945). Quantitative organic micro analysis. 4th Ed. J. Chundril, London.

Pramod Kumar, S., C. Varun Kumar and B. Bandana (2010). Effects of salicylic acid on seedling growth and nitrogen metabolism in cucumber (Cucumis sativus I). J. Stress Physiol. \& Bioch., 6 (3): 102-113.

Rizwan, M. Ali, S. Ibrahim, M. Farid, M. Adrees, M. Bharwana and S. A. Etal (2015). Mechanisms of silicon - mediated alleviation of drought and salt stress in plants: a review. Environ. Sci. Pollut. Res., 22: 15416 - 15431.

Romero-Arnada, M.R., O. Jourada and J. Cuartero (2006). Silicon alleviates the deleterious salt effects on tomato plant growth by improving plant water status. J. Plant Physio. 163:847-855.

Shu, L.Z. and Y. H. Liu (2001). Effects of silicon on growth of maize seedlings under salt stress. Agro. Environmental Protection, 20:38-40.

Fayoum J. Agric. Res. \& Dev., Vol. 33, No.1, January, 2019 
Abd-Elaziz. S. A A $^{1}$, et al.,

Tamer, C.E., B. I'ncedayi, A. S. Parseker, S. Yonak and O. U. Copur (2010). Evaluation of several quality criteria of low calorie pumpkin dessert. Not. Bot. Horti. Agrobot. Cluj-Napoca., 38:76-80.

Wang, L.J., S. J. Chen, W. F. Kong, S. H. Liu and D. D. Archibold (2006). Salicylic acid pretreatment alleviates chilling injury and affects the antioxidant system and heat shock proteins of peaches during cold storage. Postharvest. Biol. Technol., 41:244-25.

Wei, L., A. Xi-Zhen, L. Wen-Juan, W. Hong-Tao, L. Sheng-Xue and Z. Nan (2009). Effects of salicylic acid on the leaf photosynthesis and antioxidant enzyme activities of cucumber seedlings under low temperature and light intensity. Yingyong Shengtai Xuebao, 20(2):441-445.

Wilde, S. A., R. B. Corey, J. G. Lyer and G. K. Voigt (1985). Soil and plant analysis for tree culture. Soil sci., 116 (5): 390.

Yadava, U.L. (1985). Arapid and nondestructive methods to determine chlorophyll in intact leaves. Hort Science, 21: 1449 - 1450.

Yildirim, E., M. Turan and I. Guvenc (2008). Effect of foliar salicylic acid applications on growth, chlorophyll, and mineral content of cucumber grown under salt stress. J. Plant Nutri., 31: 593-612.

Zhu. Z., G. Wei, J. Li, Q. Qian and J. Yu (2004). Silicon alleviates salt stress and increases antioxidant enzymes activity in leaves of salt stressed cucumber. Plant Sci., 167:527-553.

Zhu, Y. and H. Gong (2014). Beneficial effects of silicon on salt and drought tolerance in plants. Agron. Sustain. Dev., 34:455-472.

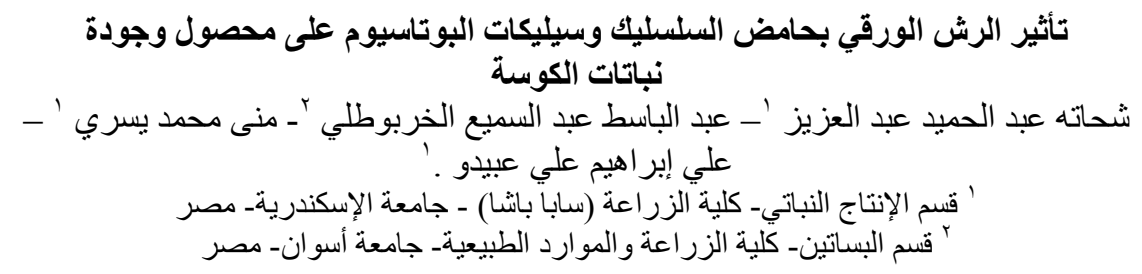

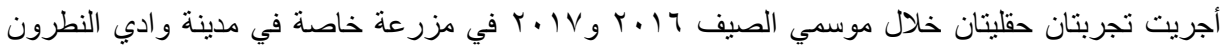

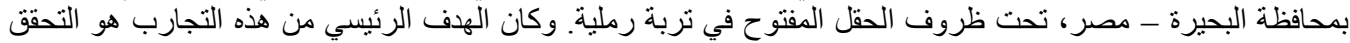

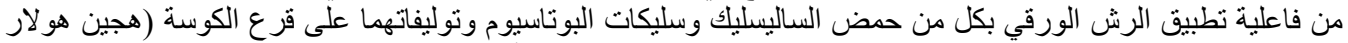

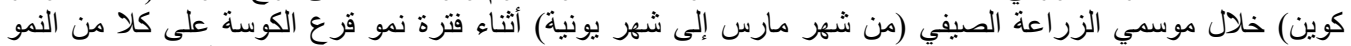

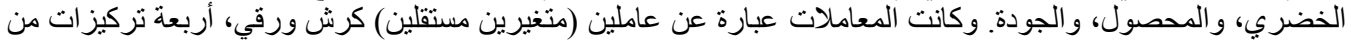

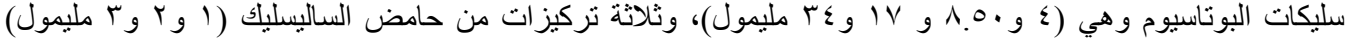

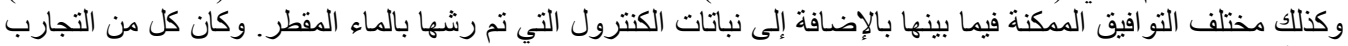

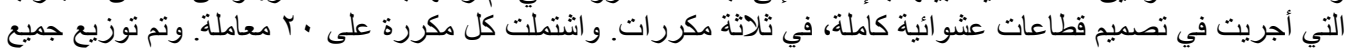

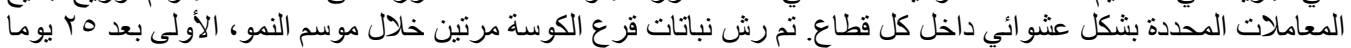

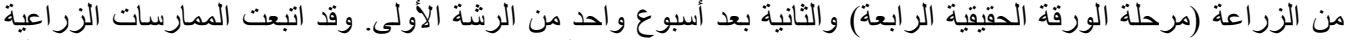

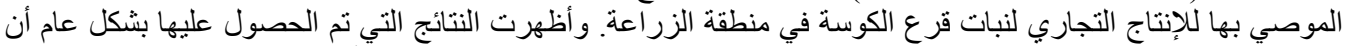

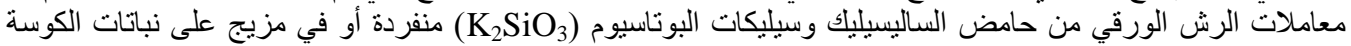

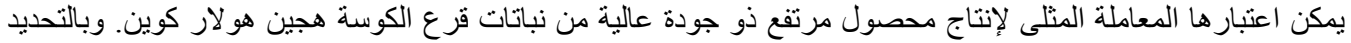

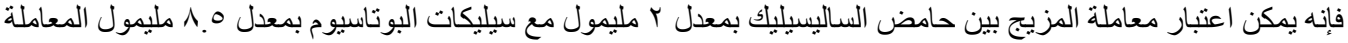

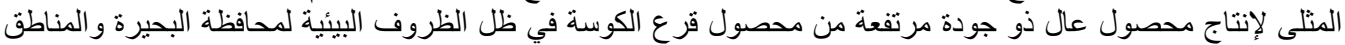

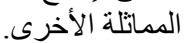

Fayoum J. Agric. Res. \& Dev., Vol. 33, No.1, January, 2019 